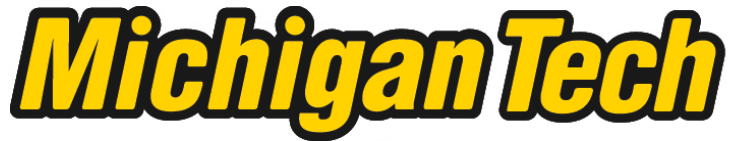 \\ Michigan Technological University Create the Future Digital Commons @ Michigan Tech
}

\section{Investigation of the effect of using data collection technology on students' attitudes to science instruction}

R. Douglas Damery

Michigan Technological University

Follow this and additional works at: https://digitalcommons.mtu.edu/etds

Part of the Science and Mathematics Education Commons

Copyright 2012 R. Douglas Damery

\section{Recommended Citation}

Damery, R. Douglas, "Investigation of the effect of using data collection technology on students' attitudes to science instruction ", Master's report, Michigan Technological University, 2012.

https://doi.org/10.37099/mtu.dc.etds/533

Follow this and additional works at: https://digitalcommons.mtu.edu/etds

8 Part of the Science and Mathematics Education Commons 


\title{
An Investigation of the Effect of Using Data Collection Technology on Students' Attitudes to Science Instruction
}

\author{
By \\ R. Douglas Damery
}

\begin{abstract}
A REPORT
Submitted in partial fulfillment of the requirements

for the degree of

MASTER OF SCIENCE

APPLIED SCIENCE EDUCATION

MICHIGAN TECHNOLOGICAL UNIVERSITY 2012
\end{abstract}

Copyright (C R. Douglas Damery 2012 
This page deliberately blank 
This project, "An Investigation of the Effect of Using Data Collection Technology on Students' Attitudes to Science Instruction," is hereby approved in partial fulfillment of the requirements for the degree of MASTER OF SCIENCE IN APPLIED SCIENCE EDUCATION

\section{DEPARTMENT OF COGNITIVE AND LEARNING SCIENCES}

Signatures:

Report Advisor

Kedmon Hungwe

Department Chair

Bradley Baltensperger

Date 
This page deliberately blank 


\section{Table of Contents}

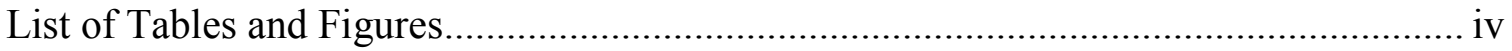

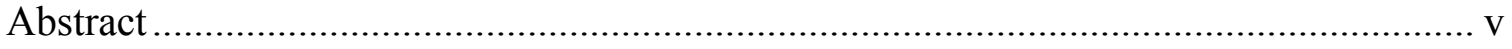

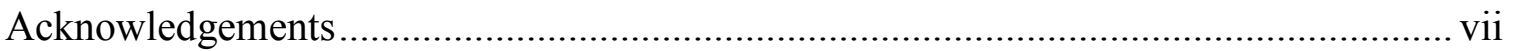

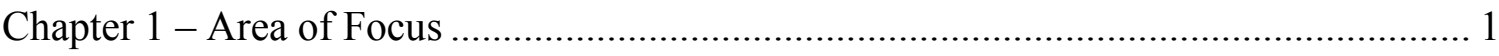

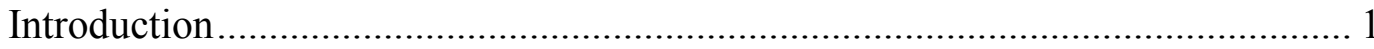

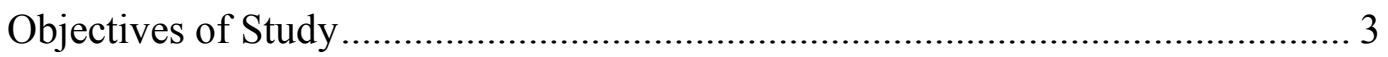

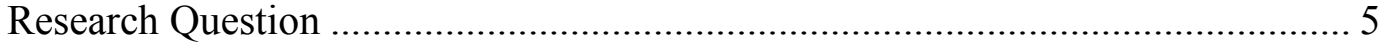

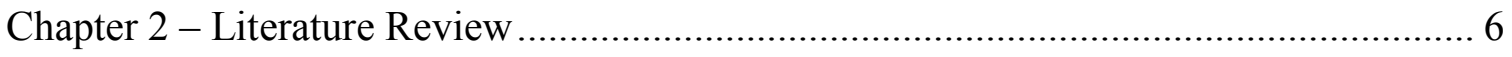

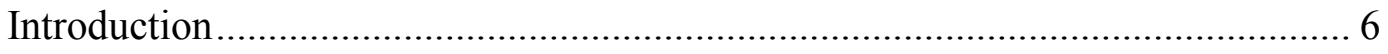

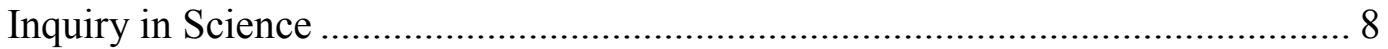

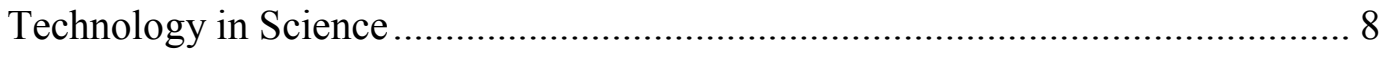

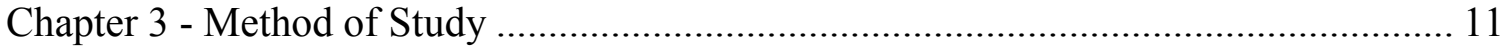

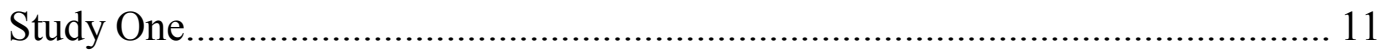

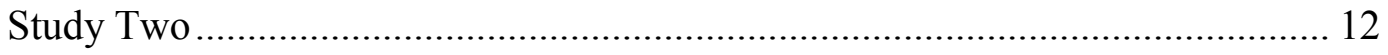

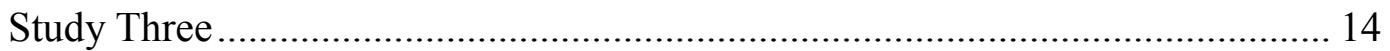

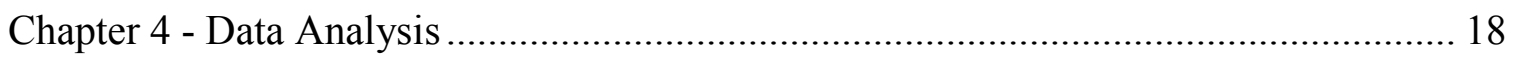

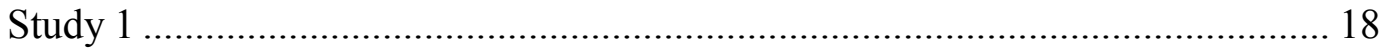

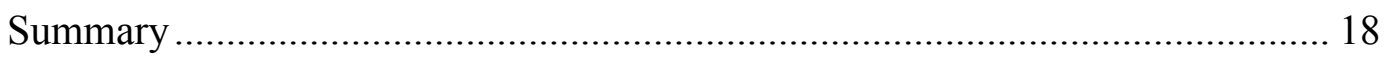

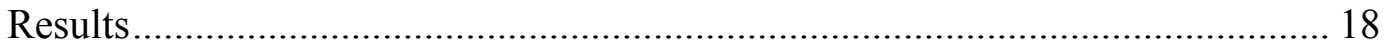

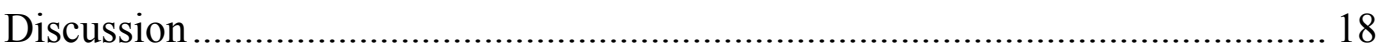

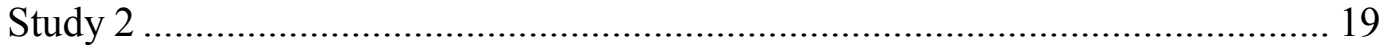

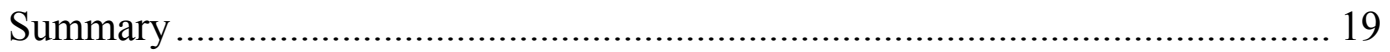




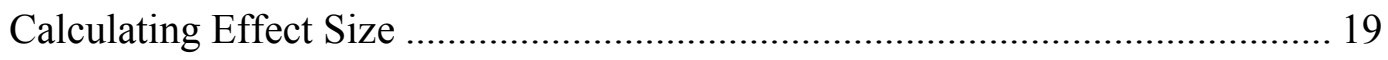

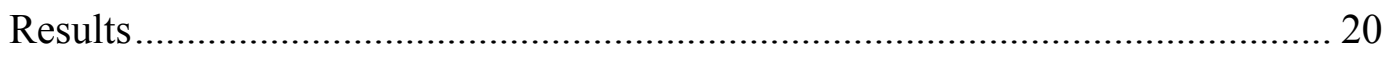

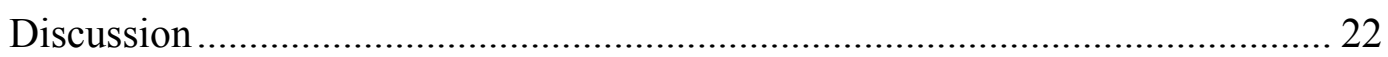

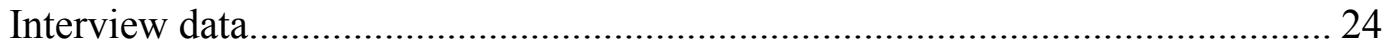

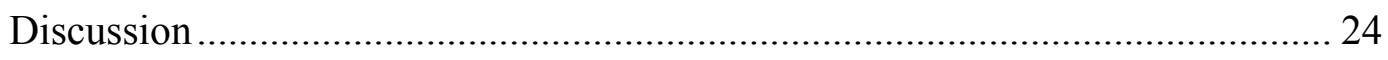

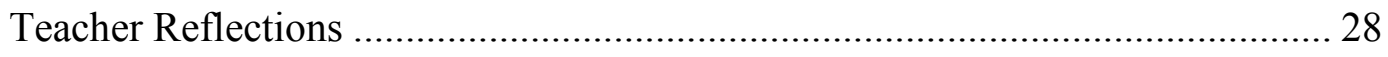

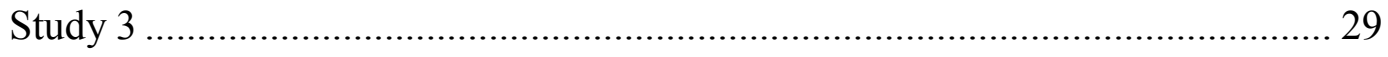

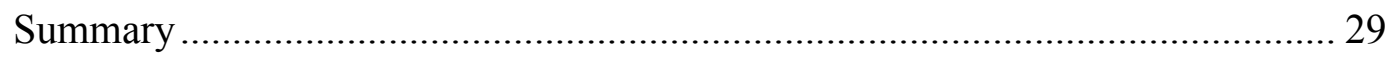

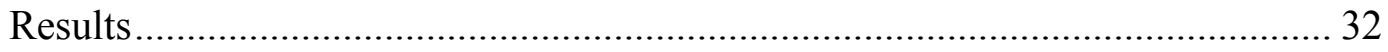

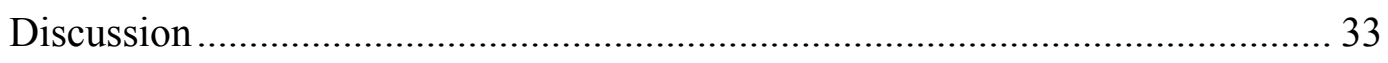

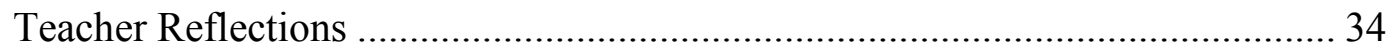

Student Investigation: Centripetal acceleration on a playground ……….............. 36

Final Teacher Reflections ............................................................................ 38

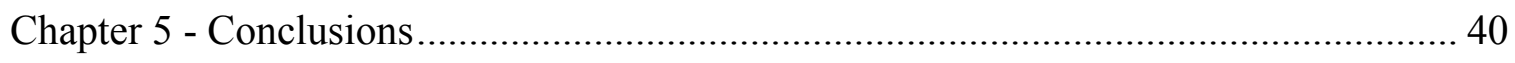

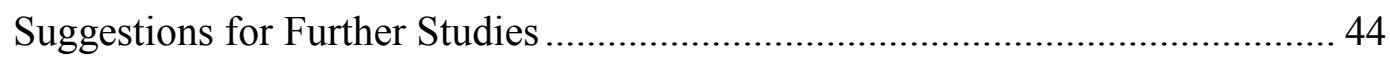

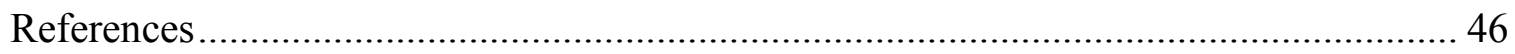

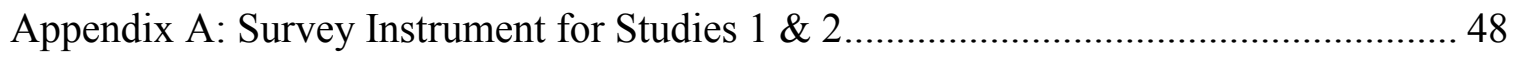

Appendix B: Interview Questions for Studies $1 \& 2 \ldots \ldots \ldots \ldots \ldots \ldots \ldots \ldots \ldots \ldots \ldots \ldots \ldots \ldots \ldots \ldots \ldots \ldots . . . .50$

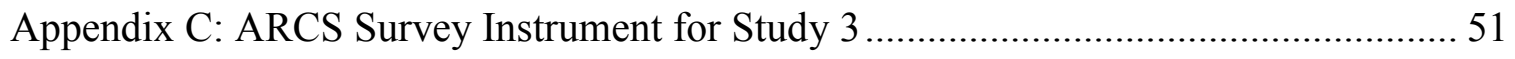

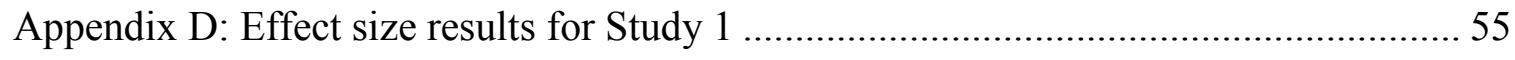

Appendix E: Effect size results for Study 2 ............................................................. 57 
Appendix F: Study 2 Interview Transcripts.

Question 1: What did you learn from using graphing calculators and probeware in this class?

Question 2: What was your favorite part about using graphing calculators and probes?

Discussion 61

Question 3: What was your least favorite part about using the technology?...... 61

Discussion 62

Question 4: How do you use computers at home?..... 62

Discussion 63

Question 5: How do you use computers at school? ..... 64

Discussion 64

Question 6: Did you enjoy using the calculator and probe to take measurements?

Why or why not?. 65

Discussion 66

Question 7: How would you make the labs better? 67

Appendix G: Average Responses for Study 3 68

Appendix H: Student Investigation 70 


\section{List of Tables and Figures}

Figure 1: ARCS Averages Response, All students ............................................ 32

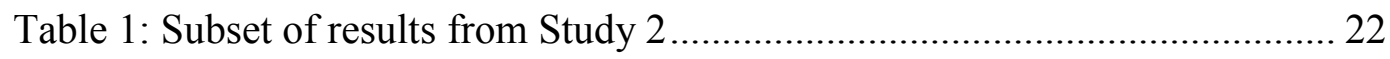

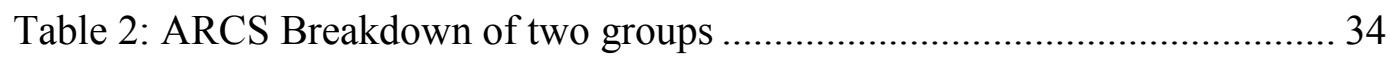

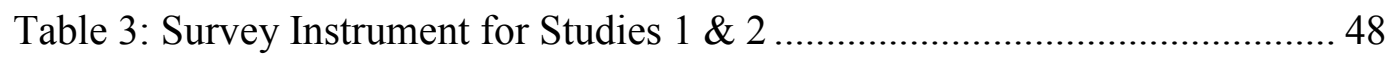

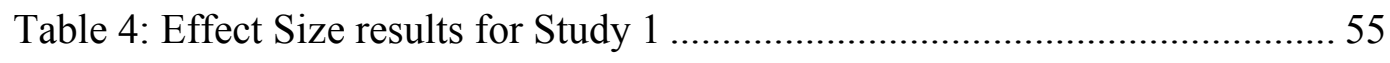

Table 5: Effect Size Results for Study 2 ................................................. 57

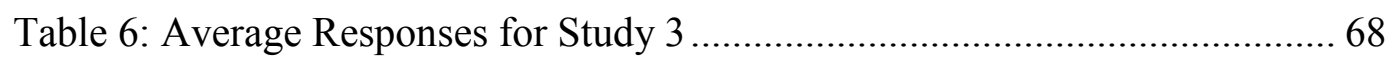




\begin{abstract}
An Investigation of the Effect of Using Data Collection Technology on Students'

Attitudes to Science Instruction
\end{abstract}

By

\title{
R. Douglas Damery
}

The purpose of this project was to investigate the effect of using of data collection technology on student attitudes towards science instruction.. The study was conducted over the course of two years at Madison High School in Adrian, Michigan, primarily in college preparatory physics classes, but also in one college preparatory chemistry class and one environmental science class. A preliminary study was conducted at a Lenawee County Intermediate Schools student summer environmental science day camp. The data collection technology used was a combination of Texas Instruments TI-84 Silver Plus graphing calculators and Vernier LabPro data collection sleds with various probeware attachments, including motion sensors, $\mathrm{pH}$ probes and accelerometers. Students were given written procedures for most laboratory activities and were provided with data tables and analysis questions to answer about the activities. The first year of the study included a pretest and posttest measuring student attitudes towards the class they were enrolled in. Pre-test and post-test data were analyzed to determine effect size, which was found to be very small (Coe, 2002). The second year of the study focused only on a physics class and used Keller's ARCS model for measuring student motivation based on the four aspects of motivation: Attention, Relevance, Confidence and Satisfaction (Keller, 2010). According to this model, it was found that there were two distinct groups in the class, one of which 
was motivated to learn and the other that was not. The data suggest that the use of data collection technology in science classes should be started early in a student's career, possibly in early middle school or late elementary. This would build familiarity with the equipment and allow for greater exploration by the student as they progress through high school and into upper level science courses. 


\section{Acknowledgements}

This project would not have been possible without the help and encouragement of the faculty and staff at Michigan Technological University. Thank you to my advisor, Dr. Kedmon Hungwe for his guidance and encouragement throughout this process. I would also like to thank my family for their understanding, patience and support. Most especially I would like to thank my wife, Krista, who has put up with my absences during this process, both physical and mental. It is she that helped me remember when I was most frustrated what I hoped to learn from this project. She has always seen how much further I am capable of going, even if sometimes I didn't see it myself. 
This page deliberately blank

viii 


\section{Chapter 1 - Area of Focus}

\section{Introduction}

Before I entered the education field, I worked for two years teaching adults how to operate their personal computers and the programs that many had installed on them. It became clear to me during that time that many of the tasks that we as a society used to do manually, we were now beginning to do with computers and technology. For example, many households at the time had one book that contained all of the names, addresses and phone numbers of everyone that they knew. One of the classes offered by my employer at the time involved constructing a database to organize, search and manipulate that same set of information electronically.

At the same time that I was working as a computer instructor, the Internet and World Wide Web began to develop as a mainstream tool that people were using in their homes and places of business. Many people were beginning to have dial-up connections and most businesses were installing permanent, high-speed connections in their offices.

When I went back to school to get my teaching certificate in 1999, I was excited when I learned I would be taking a class titled "Educational Technology." I envisioned learning how to use interactive technology to teach my students. I wanted to learn about graphing calculators and data collection equipment like I had used in my college classes in the previous seven years. I was disappointed that the class only taught me how to analyze test scores with a spreadsheet and how to use an overhead projector and a few other pieces of equipment. I concluded that if I wanted to learn 
how to integrate technology into my teaching, I would have to learn how to do so on my own.

Since that time I have attended every workshop or conference session that I could find on how to bring technology closer to students. My goal has been to get as much technology into the hands of my students as I could, in a format that they can use to improve their learning. At first, I wanted technology for technology's sake. I didn't care what it was or whether or not it was easier or harder to use than other ways of learning. I just wanted to expose my students to technology.

Gradually, I have come to realize that to truly impact student learning, the technology must be meaningful and bring something new to student learning. In science, that means making the concepts either easier to understand or easier to explore. That is why the main focus of technology in my classroom has been the use of data collection probes and graphing calculators.

Initially, I began implementing probeware into my Physics course. I started with motion detectors and gradually added other equipment, including accelerometers, force sensors and photogates. After three years, my students and I were becoming comfortable with the equipment and how to draw meaning from what we were seeing in the data. That year I decided to add sensors to the Environmental Science and College Preparatory Chemistry classes that I was teaching. My objective in adopting data collection sensors was to bring more realistic and meaningful data into my teaching to help students understand science.

Unfortunately, I am the only science teacher at my school that has found value in using this equipment. I have tried to show the other teachers that they can adopt 
this equipment in their curricula in a meaningful way. I hope that through this study I can show my colleagues and others that the use of data collection technology adds to the learning experience of the students in a measurable way.

\section{Objectives of Study}

In the State of Michigan, the Department of Education has spelled out what things students should understand and be able to do by the time they reach the end of their junior year of high school, the Michigan Merit Curriculum. In science, those objectives are divided into four major disciplines, Biology, Chemistry, Physics and Earth Science. Each of these disciplines is further divided into either four or five sections each. The only section that is common throughout all four disciplines is the first, Inquiry, Reflection and Social Implications. In this expectation, all four disciplines contain the same nine expectations, all of them dealing with the inquiry process and analyzing data to support scientific ideas. The expectation that drove me to use data collection equipment is expectation 1.1d: Identify patterns in data and relate them to theoretical models (Michigan Department of Education, 2006).

In physics, specifically in kinematics (the study of motion), there are very distinct relationships between position and time, velocity and time and acceleration and time. These relationships can be seen very clearly if position, velocity and acceleration are graphed against time. On a position versus time graph, the slope of the line is velocity and how that line changes is acceleration. If velocity is graphed against time then the slope of the line becomes acceleration.

By using data collection equipment, students can collect data for various situations of motion, specifically a cart rolling at a constant velocity on a level track 
and a cart rolling uphill, stopping and then rolling back down hill (constant acceleration but changing velocity). By collecting data on these situations students should be able to see the relationships between position, velocity, acceleration and time.

The use of data collection equipment can go beyond the physics classroom. It can also be used in environmental science, chemistry, biology, earth science, in short, all science classes. When developing this study, I wanted to ask a question that went beyond just one class, but transcended all science disciplines. I wanted to know if the use of technology encouraged students to engage in the science classroom more, to be motivated to study science. Essentially, I wanted to know if the use of technology changed student attitudes towards the study of science.

In studying the use of technology in lab science classes, it is my hope to find evidence that the use of technology, particularly data collection equipment, improves the learning experience of the students involved in the course. Data collection equipment is used especially in the laboratory setting, following laboratory procedures that have been developed by the manufacturer of the sensors, Vernier Software and Technology. The laboratory procedures are published in a series of books. The activities used for Physics are from the text "Physics with Vernier" (Apel, Gastineau, Bakken, \& Vernier, 2007) and the Chemistry activities are from the text “Chemistry with Vernier” (Holmquist, Randall, \& Volz, 2007). 


\section{Research Question}

The research question that was asked was:

What effect does the use of data collection technology have on students enrolled in a laboratory science class?

1. Does the use of technology affect students' attitudes towards science?

2. Does technology use affect student's attitudes towards technology in science? 


\section{Chapter 2 - Literature Review}

\section{Introduction}

Classrooms are particular to individual teachers. The social and educational values of the teacher are imbedded into the classroom. Also, the individual students play a role in defining a particular classroom. A different group of students will create a different set of dynamics within the classroom. Different students also bring their own unique set of skills, attitudes and knowledge to the classroom. There is no one set of teaching strategies that is likely to be most effective with all students (Yerrick \& Johnson, 2009).

When considering how best to teach science, the diversity of students and also how they learn best, should be considered. The traditional teaching styles in secondary and post-secondary classrooms emphasize lectures, notes and textbooks. However, most students do not consider themselves strong learners when it comes to these types of instructional environments (Yerrick \& Johnson, 2009).

A large portion of the student population considers themselves to be kinesthetic, or hands-on learners. These types of classroom activities include hands-on labs, interactive simulations and demonstrations. Another large portion of the learner population consider themselves to be visual learners, which includes the use of pictures, diagrams, graphs and simulations showing change over time (Yerrick \& Johnson, 2009). Neither of these two types of learners would be addressed in the traditional, lecture-notestextbook classroom.

Science students consistently cite as one of the reasons they like science class is that they enjoy their time in the laboratory. Many studies have shown that laboratory 
activities have resulted in increased student interest in and attitudes towards in science. It has been consistently shown to improve students' motivation and enjoyment in learning science. It is also an important medium in stimulating interest in science. (Hofstein \& Lunetta, 2004).

One of the most important areas that are considered when varying the science learning environment is also the laboratory. Variations in the laboratory space affects how students develop their understanding of scientific concepts and their perceptions of science (Hofstein \& Lunetta, 2004).

One reason for the focus on this area of the science classroom is the environment that exists in the laboratory. The laboratory is a place in the classroom that is usually more informal than a lecture setting. Students can work in a cooperative manner and are encouraged to work in small groups (Hofstein \& Lunetta, 2004).

The laboratory is also a place where students and teachers have a more cooperative relationship. These cooperative interactions provide an opportunity for students and teachers to promote positive learning environment (Hofstein \& Lunetta, 2004).

Laboratory activities must also serve a purpose. These activities can be used to enable students to construct scientific knowledge. However, many teachers do not engage students in these activities. Therefore students are less likely to construct their own knowledge. Many teachers do not see it as important to help students understand how scientific knowledge is formed. As a result, students often fail to understand the relationship between the design of the laboratory activity and the purpose of that activity (Hofstein \& Lunetta, 2004). 


\section{Inquiry in Science}

One philosophy that is currently driving science education is a focus on inquiry. Inquiry in turn is a derivative of constructivism (Hofstein \& Lunetta, 2004). Constructivism in learning is centered on the premise that knowledge is not simply a copy of an idea that is passed from the teacher to the learner. Rather, a learner builds up a set of knowledge based upon their experiences, understandings and previously constructed ideas (Phillips, 2000). When implemented, this is quite a different approach to science learning when compared to traditional teaching practices (Hofstein \& Lunetta, 2004).

When the Framework for K-12 Science Education was released in 2012, one of the main focuses of the document was on inquiry learning (National Research Council, 2012). In order for schools to meet the expectations laid out in the framework and the previous National Science Education Standards, technology will also have to be a part of the way teachers address learning (Yerrick \& Johnson, 2009).

\section{Technology in Science}

Technology can also be used to encourage inquiry in the classroom. inquiry empowering technologies (Hofstein \& Lunetta, 2004) help students to gather, organize, visualize and interpret data.

"When inquiry empowering technologies are properly used by teachers and students to gather and analyze data, students have more time to observe, to reflect, and to construct conceptual knowledge that underlies the laboratory experiences. In addition, the associated graphics offer visualization that can enhance students' understanding." 
Yerrick \& Johnson (2009) found that when data collection technology was used in the laboratory students were more engaged and more motivated. Also, they were better able to assimilate the information they learned. Students reported that the reason for this was the technology-rich environment. In interviews, students related experience with not just the technology, but also with the concepts being taught with the tools.

Technology in the classroom enables teachers to address the different learning styles of their students. This includes supporting the construction of student knowledge through concrete experience, reflective observation, abstract conceptualization and active experimentation (Solvie \& Kloek, 2007). The use of probeware also enabled students to develop a deeper understanding of the relationships being discussed. Teachers have observed that students' ability to read graphs, problem solve, work cooperatively in groups and asking questions and figuring out how to answer them helped students to gain a deeper understanding of scientific concepts (Metcalf \& Tinker, 2004).

Using probeware in the laboratory facilitates student learning of complex relationships. Use of models and simulations also allow students to learn complex dynamic relationships that might otherwise be too difficult using traditional methods (Metcalf \& Tinker, 2004).

The laboratory in today's science classroom is an especially valuable tool, especially with the national focus on inquiry learning as the preferred method of teaching and learning science (National Research Council, 1996). The science laboratory is important in the attempt to vary instructional environments for different types of learners. Laboratory experiences offer a process for learning science, rather than disjointed, discrete parts of the scientific process (Hofstein \& Lunetta, 2004). The use of technology 
in the laboratory adds further value to the laboratory experience by allowing teachers to spend less time covering content, but still enjoying a high level of achievement for their students (Yerrick \& Johnson, 2009). The most powerful learning environments are those that enable students to perform complex tasks with teacher support, including feedback and assessments (Linn, 2003). 


\section{Chapter 3 - Method of Study}

The methods for this overall study can be broken down into three distinct smaller studies: Study 1, the preliminary study, Study 2, the initial classroom study and Study 3, the secondary classroom study. Conducting the study in three phases allowed for changes to be made to the study in an attempt to collect better data from the students.

\section{Study One}

The preliminary phase of the study involved measuring the attitudes of a very small sample of students enrolled in a science workshop offered by the local intermediate school district (ISD) in the summer of $2009^{1}$. This was essentially a proof of concept study, whereby the students were given a task to complete involving the collection of experimental ecology data using electronic data collection equipment and software.

The county where the ISD is located has a mix of rural, suburban small town and medium-sized city. There is a large population of minority families living in the county seat, with very few minorities in the outlying communities. Many county schools have large populations supported primarily by agriculture, with a large number of families deriving their livelihoods from manufacturing and service sectors, as well.

The students in the workshop were six non-minority students enrolled in various county schools. There were two girls and four boys involved in the workshop. Students self-selected to participate in the workshop. There was a small fee required for enrollment in the workshop, collected by the ISD.

\footnotetext{
${ }^{1}$ This portion of the study is covered under Michigan Technological University's
} 
Students were given a pre-survey designed to measure their attitudes towards school, science learning and the use of technology in school. They were then shown how to use the equipment to collect experimental data, in this case, light intensity. The day after they collected the data and were shown how to analyze it, students were given a second, identical survey to measure the change in their attitudes on the fifth day.

The survey instrument (Appendix A) is an adaptation of the instrument used by Kind, et al (2007) to develop measures for science attitudes. The instrument was adapted to a five-point Likert scale in this study. It was further modified to include five questions that were specific to the use of technology in science education and learning.

After the survey was given, students were interviewed using seven questions (Appendix B) to try to further understand student attitudes and how the lesson affected their attitudes. The interviews were not recorded, but notes were taken regarding the student responses.

\section{Study Two}

The second phase of the study, the initial classroom study, was conducted beginning in September of the school year immediately following the preliminary study ${ }^{2}$. It took place in a mixed high school science classroom. The school is in the same county as the summer program, and has a mix of urban, rural and suburban students. There is

${ }^{2}$ This portion of the study is covered under Michigan Technological University's Office of Research and Integrity Protocol \# M0475, from August 3, 2009 through August 2, 2010. 
also a mix of different economic and ethnic groups. About two-thirds of students attending the school qualify for free and reduced lunch, one third are of Hispanic ancestry, less than 25-percent are African American and just over half are Caucasian.

The general structure of the classroom study followed the pretest, treatment, posttest, interview structure used in the summer camp study; however, the time between pretest and posttest was either 12 weeks of study 24 weeks of study, depending on the course. One class surveyed was the second half of a college preparatory chemistry class. This class used a $\mathrm{pH}$ probe to graph the change in $\mathrm{pH}$ during an acid-base neutralization laboratory. The second group was two sections of a one-trimester long environmental science class. This group did the same experiment that was conducted during the summer camp. The final group was a physics class that used several different types of data collection equipment throughout the course of the two-trimester course.

All classes in this portion of the study were given the pretest within the first week of the course. Then, the class was taught as normal, with the exception of the use of data collection equipment. This included the use of PowerPoint lecture notes, interactive whiteboard and other delivery technology. After the students were exposed to the use of the data collection equipment and shown how to analyze the data using the software, they were then given the post-test survey. The data from pre- and post-tests was analyzed for significant change in attitudes after the treatment and a sample of students was selected for interviews. Five students were selected because they showed a larger change in attitude in several key questions relating to the use of technology. Unfortunately, only four of these were recorded and transcribed. The fifth recording was lost due to a data loss event and was not transcribed. 


\section{Study Three}

The initial phase of data collection showed very little change observed in student perception. As a result, it was determined that a third phase of data collection should be undertaken, this time looking at a different aspect of student perception, based on John Keller's ARCS Model of Motivational Design.

The ARCS Model of Motivational Design is an approach to designing learning environments to help encourage student learning and sustaining that learning by addressing four key factors in motivating learning: Attention, Relevance, Confidence and Satisfaction. The idea is that if a student is not motivated, they will not be as likely to learn the material. With that in mind, it is important to understand these four parts of motivation in order to design lessons and courses that will promote learning (Keller, 2006).

Attention, according to Keller, is broken down into three subcategories, perceptual arousal, inquiry arousal and variability. The first is achieved through the use of various presentation techniques, including humor, active participation and the use of conflicting and incongruous events. Inquiry arousal is the use of open-ended questions and activities where the learner is asked to solve a problem or develop a list of ideas through brainstorming activities. Finally, variability is the use of different types of activities in order to access different individuals' learning styles (Learning Theories Knowledgebase, 2012). This can be done through the use of short presentations, video lessons and segments, and different types of group discussions and activities.

Relevance is showing the learner that the lessons covered are worthwhile to them, either in the present, or in the future. Does the learning meet their goals for the future? 
Is it something that they can benefit from right now? This relevance should be shown using language that is familiar to the learner and also by using examples and syllabi to explain the learning outcomes expected in the course. Relevance can also be achieved by allowing students a choice in how to complete some assignments, such as completing a final project as a report, a video, a poster, or other similar activity (Learning Theories Knowledgebase, 2012).

The confidence segment of Keller's model addresses a student's opinion of their ability to succeed at the given task. It can also be a measure of how worthwhile the task is to the student. If either the perception of the cost, in time or effort, is too great for the perceived outcome or if their opinion of success is too low, then a student's motivation to complete the task will be reduced. (Learning Theories Knowledgebase, 2012)

In order to increase a student's confidence in a learning task, lessons can be designed to allow for more scaffolding. Providing these incremental steps reduces the anxiety that may be produced if only large tasks were presented, and not broken down into more manageable steps. Providing feedback on their progress in completing those steps will also work to reduce the anxiety level in learners. In addition, giving students an amount of control over their learning and the assessment of that learning will also contribute to increasing their confidence. If students are more invested in the process they will be more likely to see it as relevant and attainable (Learning Theories Knowledgebase, 2012).

The last area of Keller's ARCS model is satisfaction. Student satisfaction can be as simple as enjoying what they are doing. A more measurable way to increase satisfaction is by providing feedback to the learners as they are progressing through the 
lesson. This feedback and encouragement should not be overdone or exaggerated so that it becomes patronizing. It must be genuine. In addition to feedback, allowing students to apply their learning in a meaningful way will also increase satisfaction. "When learners appreciate the results, they will be motivated to learn. Satisfaction is based upon motivation, which can be intrinsic or extrinsic (Learning Theories Knowledgebase, 2012).”

With these ideas in mind, the third phase of data collection was begun using an instrument designed to measure students' perceptions based on Keller's ARCS model ${ }^{3}$. The instrument (Appendix C) is a modified version of Keller's (2010, p. 283) Instructional Materials Motivation Survey, with questions reworded to make them relevant to an entire course, rather than only one lesson. Also, five questions were added to draw focus to the use of technology in the course as a method of improving motivation.

As administered, the instrument consisted of a series of 37 questions which contained 13 questions assessing attention, 10 assessing relevance, nine assessing confidence and five measuring satisfaction. Eleven of the questions (nos. 3, 6, 11, 14, 18, $21,25,30,32,33$ and 35$)$ were included on the questionnaire, but were removed from analysis because of suspected confusion due to the way they were worded. Five of these

${ }^{3}$ This portion of the study is covered under Michigan Technological University’s Office of Research and Integrity Protocol \# M0742, from April 1, 2011 through March $31,2012$. 
removed questions addressed attention, three confidence and one each relevance and satisfaction.

Another change in this phase of the study was that instead of looking at chemistry, environmental science and physics, attention was focused only on the course with the most use of data collection equipment, the college preparatory physics class. The class was taught essentially as it has been taught in past years, with the exception that two to three more laboratory exercises were added to the course. The survey was administered in the second of two trimesters, as the course was drawing to a close. 


\section{Chapter 4 - Data Analysis}

\section{Study 1}

\section{Summary}

This small-scale pilot study was conducted during a one-week summer enrichment program offered by the local Intermediate School District at a local natural area. There were six students participating in the program, which focused on the ecology of the local area. Students were given a pre-treatment survey (Appendix A) on the second day of the five-day camp. The survey was designed to measure the effect of the use of technology on students' attitudes towards science. On the fourth day of the camp, they were presented a lesson on how different areas of park, including woodland, margin and meadow, contain different types of vegetation.

\section{Results}

The overall mean for the attitude scale was 3.65 for the pre-test, and 3.82 for the post-test, and 0.17 was the overall gain. No firm conclusions could be drawn because of the small size of the sample. However the data did suggest that an effect could be achieved with a larger sample. The data also showed that the group was above average in their attitude scores, as compared to Kind, et al (2007), with mean scores on most items being greater than 4 (The full data set is in Appendix D).

\section{Discussion}

The data suggested that the instrument could be used to measure the effect of an instructional innovation. A follow up classroom study was therefore implemented. In addition to the attitude survey, interviews were also added in study 2 . 


\section{Study 2}

\section{Summary}

The second study involved surveying students in a traditional high school science class setting. This was the first opportunity to consider the connection between the use of technology and student attitudes towards science in a classroom setting. The number of participants in the study was 52 students. It was hypothesized that they would show an increase in interest in science and also an increase in their views of the benefits of technology in their science lessons.

Various metrics were calculated for each of the questions the group answered, including the mean score for each question, the average change between pre- and posttreatment surveys for each question, and the overall average change for the group. The most important metric, however, is the effect of the treatment on the subjects.

\section{Calculating Effect Size}

By looking at the effect size of the treatment, it is possible to answer the question “did the use of technology change attitudes in science?" Using Cohen's calculation for effect size, shown below as d, the size of the different groups is removed from the calculations allowing consideration of only how the treatment affected the study group.

$$
d=\frac{\overline{x_{t}}-\overline{x_{c}}}{s_{\text {pooled }}}
$$

In this equation, the size of the groups is removed by taking the change in the average scores of the pre- and post-treatment surveys ( $\overline{x_{c}} \& \overline{x_{t}}$ respectively), either for one question, one class or the entire study averages, and dividing that difference by the pooled standard deviation $\left(\mathrm{s}_{\text {pooled }}\right)$. 


$$
s_{\text {pooled }}=\sqrt{\frac{\left(n_{t}-1\right) s_{t}+\left(n_{c}-1\right) s_{c}}{n_{t}+n_{c}}}
$$

In this equation $n_{c}$ is the number of subjects in the pre-test and $n_{t}$ is the number of subjects in the post test. The standard deviations for the pre-test and post-test are represented by $s_{c}$ and $s_{t}$, respectively.

A small effect size is considered to be between $d=0.20$ and $d=0.49$. A medium effect would begin at $\mathrm{d}=0.50$ and a large effect would be above $\mathrm{d}=0.80$ (Thalheimer $\&$ Cook, 2002). For purposes of this study, a very small effect is considered to be between $\mathrm{d}=0.10$ and 0.20 .

To find the pooled standard deviation, one less than the number of subjects in each part of the study $\left(\mathrm{n}_{\mathrm{t}} \& \mathrm{n}_{\mathrm{c}}\right)$ was multiplied by the standard deviation of that part $\left(\mathrm{s}_{\mathrm{t}} \&\right.$ $\mathrm{S}_{\mathrm{c}}$ ). The two products were added together and divided by the total number of subjects in the study. The square root of the quotient is the pooled standard deviation (Coe, 2002).

\section{Results}

The complete results, shown in Appendix E, showed no effect, with the pre- and post-test means of 3.45. There were a few items that showed encouraging effects, as shown in the subset of the result are shown in 
Table 1. "Science is one of my best subjects," "I learn science quickly," "science and technology are helping the poor," "I would like to do more science activities outside of school," all showed a small effect size. This suggests that there was some shift in how students thought about science, but these results are not definitive. 
Table 1: Subset of results from Study 2

\begin{tabular}{|r|c|c|c|c|}
\hline Question & $\begin{array}{c}\text { Pre- } \\
\text { Test } \\
\text { Mean }\end{array}$ & $\begin{array}{c}\text { Post- } \\
\text { Test } \\
\text { Mean }\end{array}$ & Change & $\begin{array}{c}\text { Effect } \\
\text { Size }\end{array}$ \\
\hline We learn interesting things in science lessons. & 3.83 & 3.92 & 0.10 & 0.11 \\
\hline I learn science quickly & 3.02 & 3.29 & 0.27 & 0.23 \\
\hline Science is one of my best subjects. & 2.98 & 3.35 & 0.36 & 0.29 \\
\hline Lab work in science is interesting. & 4.07 & 3.92 & -0.15 & -0.15 \\
\hline We learn science better when we do lab work. & 3.91 & 3.75 & -0.16 & -0.16 \\
\hline I look forward to doing science labs. & 4.05 & 3.91 & -0.14 & -0.14 \\
\hline school. & 2.97 & 3.17 & 0.21 & 0.18 \\
\hline I would like to do more science activities outside of & & & & \\
\hline I like reading science magazines and books. & 2.50 & 2.75 & 0.25 & 0.22 \\
\hline I would like to study more science in the future. & 3.28 & 3.43 & 0.16 & 0.13 \\
\hline I would like a job working with science. & 2.96 & 3.12 & 0.15 & 0.13 \\
\hline Science and technology are helping the poor. & 3.12 & 3.44 & 0.32 & 0.31 \\
\hline Overall & $\mathbf{3 . 4 5}$ & $\mathbf{3 . 4 5}$ & $\mathbf{0 . 0 0}$ & $\mathbf{0 . 0 0}$ \\
\hline
\end{tabular}

The picture is complicated by the fact that there were other items where average ratings went down. Among them were "lab work in science is interesting," "we learn science better when we do lab work," and "I look forward to doing science labs." There were also other items where the effect size was practically zero. Questions such as "I am comfortable using graphing calculators," "Science and technology make our lives easier and more comfortable," and "I work as hard as I can in school" are somewhat disappointing in their negative effect. Even more worrisome for this study is the negative effect for the two questions "I look forward to doing science labs," and "Scientists have exciting jobs."

\section{Discussion}

The data suggests that the course experience may have been too short to produce the gains of the type asked for in the survey. Questions such as "Scientists have exciting 
jobs" may have been too broad and too removed from their short experience, to produce an effect.

The fact that students experienced a negative change for these two questions, although very small, may suggest that rather than encourage a positive attitude change towards science and technology, the opposite effect may be true. While this instrument has been validated in other settings it appears not to be sensitive enough to measure impacts of short interventions. It is recommended that a shorter, sub-scale be used in future research that asks questions more directly related to the short experience. The list of items would include the following:

- Science is one of my best subjects;

- I like science better than most other subjects at school

- We learn interesting things in science lessons

- I learn science quickly

- Science is one of my best subjects

- I like to visit science museums

- I would like to do more science activities outside of school

- I like reading science magazines and books

- I would like to study more science in the future

- I would like a job working with science

The complete breakdown of results for this study is shown in Appendix E. 


\section{Interview data}

After students had completed the course, several were invited back to participate in an interview about their experiences with technology in their course. These students were selected because they showed the most change in the attitude as measured by the survey instruments. Four students, Stephanie, Jessica, Austin and Kayleigh, were a part of a junior/senior Physics class that involved biweekly instances of technology use in collecting data in a laboratory setting and daily use of graphing calculators in the classroom. Another student, Meagan, was from a sophomore college preparatory Chemistry class that had daily use of graphing calculators in the classroom, but only one instance of data collection in the laboratory at the end of the course. All interviews took place 3-4 months after their last use of probeware in the course. Unfortunately, the recording of the interview with Kayleigh was lost before it could be transcribed. All other responses were transcribed and can be found in Appendix F.

\section{Discussion}

These interviews were conducted between one and three months after the initial study took place. With that is mind, it is apparent that students were able to remember the ideas and feelings behind the use of this technology, but not necessarily fine details. They did grasp that this technology allowed them to collect data to a greater precision than would be possible without it. As Meagan stated, the technology "can be more accurate" than manual data collection methods. Also, the technology allowed students to "save things that (they) can compare later." Also, it appears that they understood that the volume of data that they could collect allowed them to make causal connections with more immediacy than without. 
It seems that by using the data collection equipment students gained a few insights into science. Students seemed to have taken away from the situation a concrete understanding of how changing certain parameters affect others. Also, students seemed to take away an understanding of the mechanics of the equipment, from connecting the components to reading the collected data from the graphs and tables.

Students seemed to trust the results they received by using the probeware more than they would if using analog equipment. They trusted the results despite the fact that the equipment was new to them and that, in general, they didn't understand how it worked.

Students also seemed to have a strong desire to understand how the equipment worked. This seemed to get in the way of the science for some of the students, as was apparent in some students' actions during the laboratory activities. Many students were so engrossed in the equipment and getting the settings right that they were not as focused on the science of the activity.

The downside of the technology for the students was the lack of familiarity in how to set up the probeware and how to correct errors in the setup if there were problems. There was definitely a learning curve in the use of this type of equipment. When the student exposure level was low, they appeared to struggle with the equipment, but as they became more familiar with it, these difficulties appeared to lessen. This problem could be easily corrected if students were given more exposure to the digital data collection equipment. This ideally would occur gradually over the course of a student's school career, but could also be accomplished within one course, with more frequent lab activities. 
This lack of familiarity could also be a contributing factor to the apparent decrease in agreement with the question "I am comfortable using graphing calculators." If students are given familiar equipment, the graphing calculator, and are asked to use it in a new way, for data collection, then their comfort level with that equipment may decrease.

These students seemed to be fairly technologically literate. They were used to interacting with computers for various tasks, both school related and personal. A few of them were even what could be considered technologically fluent, according to the MIT Media Lab description (2003). However, this technological literacy did not mean that they were able to take this new technology and immediately apply it to their learning.

Students apparently needed ample opportunity to become familiar with these new applications of technology before they could assimilate them into their learning processes. This seemed to be the case with those that could be considered technologically fluent and also with those that are not. Those like Austin that were fluent had a desire to understand how the technology worked. Those like Meagan that were less fluent had a more immediate desire to learn how to make the technology do what they wanted.

The point is that there is a learning curve to all new technology for an individual. How steep that learning curve is may depend in part on the individual's technological fluency. We cannot assume that simply because a person is technologically fluent that they will immediately grasp how to use a new technology to learn science. They must be given the opportunity to become familiar with the new technology. 
Most student exposure to technology in school appeared to be in the form of Internet research and calculators. Technology did not appear to be truly integrated into the learning environment that these students were currently engaged in. It seemed to be a more superficial presence in their learning.

Using a graphing calculator to collect data goes beyond using a web browser to do research, or Microsoft PowerPoint or Word to present the data. It even goes beyond using a graphing calculator to solve a math problem. Data collection is a continuous, dynamic interaction between the user and the equipment. To introduce students to a new type of educational technology, especially one that requires a deeper interaction with the equipment, requires an opportunity for them to become more familiar with the technology.

Students responded favorably to the use of technology, mostly because of how it made the job of data collection easier and less tedious. This was especially an aid to those students that may have struggled with mathematics, as it gave them another tool to support their learning in that area. The fact that the calculator can perform some of these tasks, like finding the equation of a line represented by the data, can help students get beyond their deficiencies in math and learn the science behind the relationships.

Students continued to express a concern over the learning curve required to effectively use the equipment, though. How can a lesson or an entire course be structured to provide the technology that helps a student's understanding of science but yet also provide enough scaffolding to build their comfort with that technology? Also, how do you bring the math back into the picture for those students that are weak in that area? To fully understand the science a person must also understand the math. 
Suggested student improvements seem to center around more training and experience using the equipment. Again, this illustrates the need to expose students to this technology earlier in their educational career. An increased familiarity with the equipment may improve student comfort and performance when using data collection equipment.

Even if a student arrives in a classroom with little to no exposure to data collection equipment, their comfort level can be increased through the course of the class. If activities were put into place that, while simple to execute, build their confidence in using the equipment, and gaining an understanding of how the equipment works, they will become more comfortable with it. This increased comfort and understanding would also allow them to be more confident in designing their own experiments.

One possible avenue that could be pursued is to start students with very basic, introductory types of investigations and then build them towards designing their own experimental questions and procedures, based upon a set of concepts that are determined by the instructor. By scaffolding their learning in this way, students can progress through a course, learning the topic material, but also gain experience with using scientific reasoning and problem solving to find answers to their own questions. The key in building a successful course would be to find the correct balance.

\section{Teacher Reflections}

The four students interviewed expressed a general acceptance of the use of data collection equipment. They understood the reasons for using this type of equipment rather than manual and analog data collection devices like stopwatches and meter sticks. They also brought to light some of the drawbacks to using this equipment as well. It is 
clear that students need to understand how the equipment works, not just that it does. This lack of understanding appeared to interfere with the topic learning that was the purpose of many of the investigations.

Students must be gradually introduced to the equipment they are being asked to use. They must understand, at least on a basic level, the way that it works and collects data. Without this knowledge, it is simply a magic box that some will find the need to probe and understand. This probing can be harnessed early in the introduction to the equipment and then gradually replaced with an interest in the science topics that are the goal of many science classes. By scaffolding the laboratory learning, beginning with learning to use the equipment and then proceeding to how the equipment works and finally ignoring the equipment and using it to investigate other ideas, the instructor can harness the natural curiosity that students have and direct that curiosity into exploring the areas of the subject that they are learning, whether that be chemistry, earth science or physics.

\section{Study 3}

\section{Summary}

The third study was designed to measure course motivation. The goal was to determine how motivating the course design was. The instrument used was based on John Keller's ARCS Model of Motivational Design. It was designed to measure the motivation of students to succeed in a course, and, to some extent, how the use of technology affected that motivation. The instrument is designed to be applied once during a course of study. It measures motivation on four dimensions: Attention, Relevance, Confidence, and Satisfaction. 
Attention addresses the ability of an activity or course to arouse the learner's attention and hold it. This is centered on the ability of an activity to gain perceptional interest though surprise and wonder and continues to inquiry arousal, or curiosity. To hold attention, there must be variety in the instruction through the use of different teaching methods.

Relevance is a measure of how the activity links to a learner's needs motives and interests. This includes tying the activity into the goals of the learner, both in the immediate sense, as well as long term goals. The relevance of an activity must match the motivation and reasoning of the learner to acquire new knowledge and must also provide them with options in their learning.

Confidence is providing the learner with opportunities for success, making sure they know how success is defined and to allow learners to attribute their success to personal effort. This can be provided through rubrics, feedback on revisions and also comments on final projects.

Satisfaction is a measure of reinforcement and reward experienced by the learner. This can be in the form of both intrinsic and extrinsic rewards for the learner. Again, this can be in the form of feedback from the instructor, but also can be in the form of enjoyment by the learner. Consistent consequences for success and failure are also a contributing factor to this measurement.

In the third study, students in a college preparatory Physics class were exposed to the same types of lessons and laboratory activities as the previous physics class in Study 2. All students were either juniors or seniors with ambitions to go on to college save one who did not aspire to any post-secondary school. Most students, however, did not 
anticipate studies in the sciences or engineering. There were 15 students that finished the class and took the survey. Twenty students originally began the course, but several dropped the course after the first half of the course was complete. Two dropped for academic reasons and two others dropped for lack of interest. One transferred to another school.

The difference between the two studies and the third study was the instrument used to measure student reactions to the lessons. The third study group was given a survey at the end of the course designed to measure their motivation using Keller's ARCS model. The survey, reprinted in Appendix C, consisted of 37 questions in total. Students we asked to rate their agreement to each statement on a five-point scale, with 1 (or A) being something they totally disagreed with and 5 (or E) being something they totally did not agree with. Letters were substituted for numerical ratings as the students were administered the survey using machine-read forms. Of the 37 questions, 13 measured attention, 10 relevance, nine measured confidence and five success. As noted earlier, however, 11 questions were worded negatively and returned poorly correlated results, so they were discarded from the final analysis. Of those removed, five were attention questions, four confidence, and one each relevance and satisfaction. 


\section{Results}

The averages for all four areas fell between 2.37 and 2.71 (Figure 1). The standard deviation in the averages, however, was quite large, between 0.81 and 1.20. This makes the range for two-thirds of values for the area with the highest average, relevance with a mean of 2.71 , fall anywhere 1.82 and 3.61. Complete results for all questions can be found in Appendix G.

Figure 1: ARCS Averages Response, All students

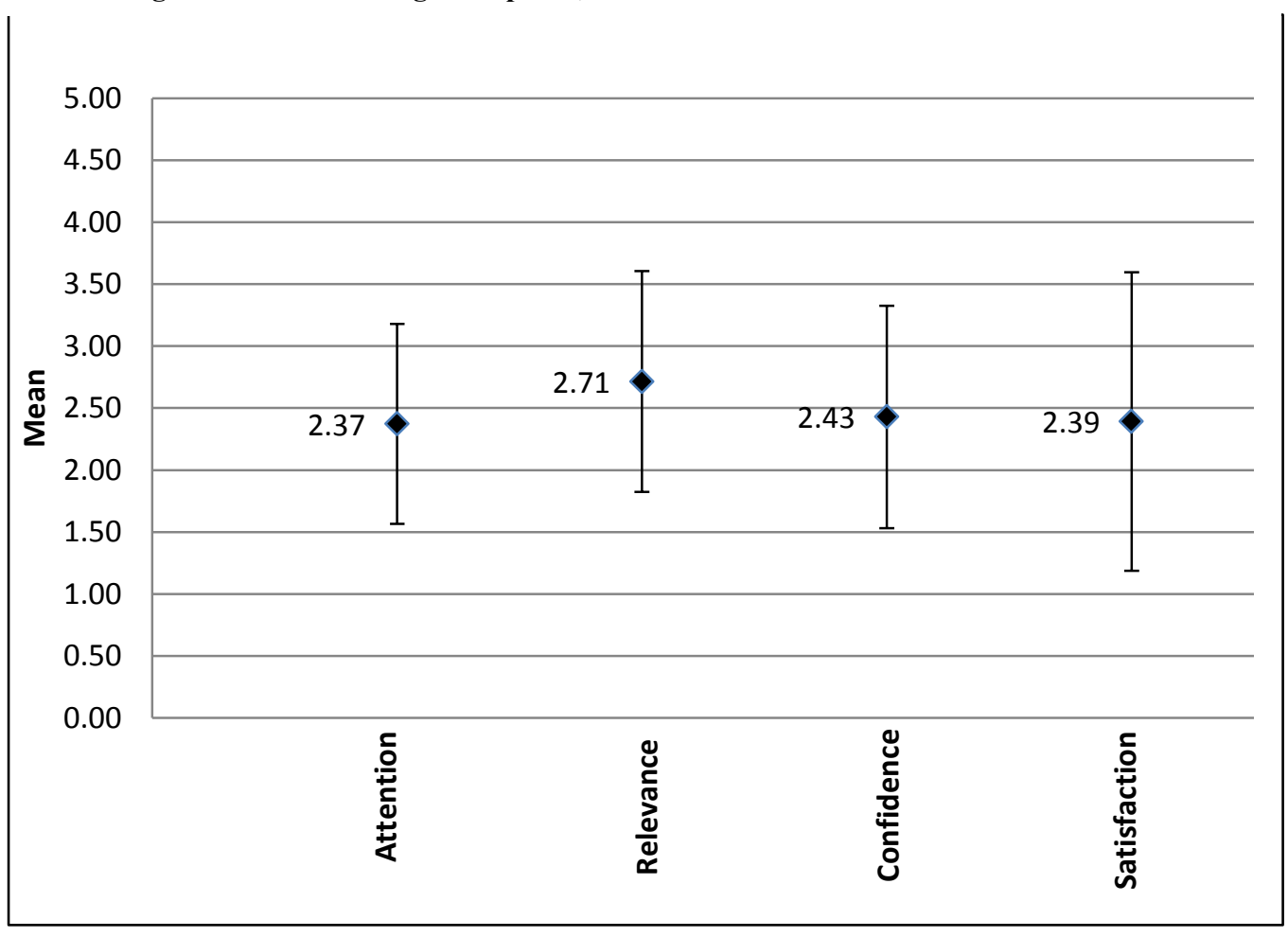

Two of the questions in the analyzed portion of the survey dealt with the use of data collection equipment in the course. The first, "The data collection technology used in this course helps me understand the material in more detail," was marked as either "not true" or "slightly true" by eight of the fourteen respondents. Five students responded with either "mostly true" or "very true." 


\section{Discussion}

In looking at the individual responses, especially the question on how important it is to successfully complete the course, it appears that there are two groups of students being surveyed. One group of eight students felt that it is mostly or very important to complete the course successfully and six students felt that it was only moderately important or less to complete the course successfully. Eleven students marked the lowest two options when asked if the course was relevant to them in question 15 and 10 students marked the same two boxes when asked if the contents of the course were relevant to their needs.

This apparent apathy in the course appears to coincide with an observation made earlier in the course. At the beginning of the second trimester of the course students were struggling with the material and they were informally polled as to who asked to be in the course and who was placed in the course by the counseling department. Six students responded that they were placed in the class and there were no other classes for them to take. Of those six, three had not met the prerequisites of the course; specifically they had not earned acceptable grades in Algebra II. One of them was enrolled in Geometry and had not taken Algebra II when the course began. These students plus one additional student, which we will call Group 1, did not put in the requisite effort to succeed in the course, as measured by completed homework, reading the textbook outside of class, and spending adequate time preparing for assessments.

There was another group of students, Group 2, of which five students did request enrollment in the course. These students behaved, for the most part, in exactly the opposite manner as the apathetic group. They asked meaningful questions in class, 
completed homework assignments on time and prepared for assessments. These students appeared to be intrinsically motivated to succeed in the course.

The breakdown of scores using the ARCS tool is shown in Table 2. The difference in scores between each group is more apparent here, with a minimum difference between the two groups of 0.53 on a 5-point Likert scale. The confidence and satisfaction measurements are much higher, with confidence being 0.91 points higher in Group 2 and satisfaction at 1.11 points higher.

Table 2: ARCS Breakdown of two groups

\begin{tabular}{|l|ccc|}
\hline & $\begin{array}{c}\text { Group 1 } \\
\mathrm{n}=7\end{array}$ & $\begin{array}{c}\text { Group 2 } \\
\mathrm{n}=7\end{array}$ & Difference \\
\hline Attention & 2.11 & 2.64 & 0.53 \\
\hline Relevance & 2.43 & 3.00 & 0.57 \\
\hline Confidence & 1.97 & 2.89 & 0.91 \\
\hline Satisfaction & 1.86 & 2.96 & 1.11 \\
\hline
\end{tabular}

\section{Teacher Reflections}

The fact that there were two distinct groups of students in this course suggests a few things about the course. First, those methods that are acceptable motivation for one group of students may not necessarily be adequate for another group of students, especially if their educational goals are different. There appeared to be one group of students that were motivated to learn the material and willing to put in a level of effort that was acceptable for the current course design. They had a desire to study the material laid out in the course description and possibly move on to further studies in this area. Several members of this first group had expressed that they wished that they had been able to move faster in the course and learn more of the material that was originally designed into the course. 
The Group 1 lacked the same level of motivation and therefore needed a course that was designed with a more robust motivational component built into it. They often expressed a desire for a less technical presentation of the material. Their lack of willingness to spend time on problem solving activities or outside reading seemed to indicate that their educational outcome goals were vastly different than those of the first group.

The second conclusion that could be drawn from the presence of two groups of students is that it might not be possible to design a course that would be able to meet the motivational needs of the second group while still allowing the first group to attain the level of learning that some of them expressed they desired. One group wanted to push forward and learn new material and apply problem solving skills to further their learning. The other group did not seem to express that desire, but instead were simply looking for a course that might fill a graduation requirement. While this is not a very encouraging goal for an instructor, it is still a valid educational goal for a student. Is it right to deprive one group of their educational goal simply to satisfy the educational goal of the other group? The two goals are possibly mutually exclusive if the motivational levels of each group are too diverse.

Aside from creating two separate courses for two motivational levels of students, another option would be to create a learning environment that can address both sets of learning goals. One model that could potentially accomplish this is a self-paced learning environment, possibly with mastery learning involved as well. In this situation, a formative assessment could be performed by each student at the beginning of a topic and, if a student demonstrates acceptable command of the material, they could move on to 
enrichment activities or deeper understanding of the material. Those that did not show mastery could be directed to complete a series of exercises that would help them to develop their knowledge of the material before moving on to another assessment. After a student demonstrates mastery of the material then they would move on to the next topic (Guskey, 2012).

This type of instructional model may hold promise in the situation described in Study 3 as it would allow for those students that are more motivated to move forward in their learning while also allowing those with a lower motivation level to still gain an understanding of the topics in the course, but at a slower pace. Instruction could also potentially be tiered, with those that pass the formative assessment the first time being allowed to gain more technical learning on the topic, including advanced problem solving, self-directed laboratory investigations or exploratory activities. This would allow for addressing some of the ideas expressed by students in Study 2, where they wanted to learn more about how the data collection equipment worked.

\section{Student Investigation: Centripetal acceleration on a playground}

One activity that was a part of the Physics class was a guided inquiry laboratory investigation that used the data collection probeware to investigate aspects that dictate pendulum movement, specifically a playground swing. A copy of a student report from this activity is included in Appendix H. In this investigation, students were given the use of an accelerometer and instructed to investigate the parameters that might affect the centripetal acceleration of a pendulum. Some groups decided to measure how different starting angles for the pendulum affected the acceleration of the pendulum. Other groups chose to measure how the mass at the base of the pendulum affects the acceleration. 
I included this activity in the course because I wanted the students to take more ownership in their learning, especially in the laboratory. Students at the school that I teach at are seldom exposed to laboratory activities that are not directed by the instructor. They are not comfortable with the aspect of science where they are given a question and not given the process by which to answer that question. In this case, the students were given no procedure, no data tables and no expectations for how to answer the question.

Students were given some basic instruction on how to use centripetal acceleration in a pendulum. They were also by this point familiar with the relationships between force, mass and acceleration and also Newton's First Law of Motion, which states that an object will move at a constant velocity in a straight line unless acted upon by an outside force. Therefore they understood that for an object to move in a curved path, there must be a force acting on the object, oriented towards the center of a circle that defines the curved path.

As students developed their procedure, usually as they went along, they were sometimes given guidance as to what aspects of their procedure would work and which would not. Many times, however, when they asked if they should do something, they were simply told to "try it and see what happens."

All groups used the accelerometer fastened to the sing chain and oriented where the detection axis was aligned with the swing chain. This way they would be measuring the centripetal acceleration of the swing as it moved. Groups also used an inclinometer fashioned from a protractor and a plumb-bob held on the other swing chain. This allowed them to determine the starting angles of their swing-pendulum. Those that were varying the angle ran several trials at different angles. Those groups that changed mass ensured 
that each trial was at the same angle, but they changed which group members rode the swing in order to vary the mass.

This was, by far, the most popular lab activity for this class. In part this is because it was conducted outside on the elementary playground, but also because students were allowed to create their own methods for answering the question. In observing the students it was obvious that, while they were struggling with creating their own procedure, they were enjoying what they were doing. They were talking to their group members and bouncing ideas off of each other. Groups were helping each other with setting up the equipment correctly and giving each other tips about how to get the best results out of their setup.

If this were the only evidence available, this would be enough for many educators to say that this is how science should be taught. It is through this active engagement and cooperation that true learning takes place. If this environment can be created and sustained students will be more excited about the material and therefore more engaged in their own learning.

\section{Final Teacher Reflections}

All of the situations described above only give part of the picture. The real reason for even trying to discover what improves student attitudes towards science is to support and motivate students to learn. The two years involved in this study have brought many different insights, only a few of which have been captured in this data.

In every group of students studied, when they began collecting data they became much more animated and interested. Their problem solving skills became engaged and they interacted with each other more. They also asked more questions, both about the 
procedures they were following but also about the science concepts involved. It was obvious that the students enjoyed actively learning.

The question now becomes how to better use technology to activate student engagement and motivation. This study highlights the need to support student interest in the scientific process. Using technology may be one tool that can be used to help students build on their scientific learning. Collecting meaningful data in the laboratory will help students use their reasoning skills to draw conclusions about ideas in science, and also to understand how the scientific process works. With the forthcoming Next Generation Science Standards (NGSS), the direction for science education seems to be moving towards that same idea. While the National Science Education Standards have placed emphasis on scientific thinking and problem solving skills, the NGSS, which are being adopted by the majority of states, will bring those ideas into more science classrooms. 


\section{Chapter 5 - Conclusions}

Science learning is changing from what it was thirty years ago. It has had to. The days of having students sit in a lecture room and listen to a person tell them about science is over. It is not the best way to get students engaged in science and to seek out careers in the science and engineering fields. It's boring. There is nothing in that type of learning that shows them what they would be doing if they did go on to become a scientist. We have to do better at educating our students in the sciences.

Successful science programs have always included at least some portion of laboratory instruction. From personal experience, labs in the 1970s and 80 s were a written series of instructions that the students followed. Their success depended upon how well they were able to follow the instructions and perform the required laboratory skills, such as measuring, separating, timing and mixing. There was no creativity in the laboratory, unless you had an exceptional teacher. Individual research didn't happen until much later in college or graduate school studies. If a student were not already interested in science, if they didn't learn with the methods that were common at the time, then the chances of them being interested in a career in science were slim.

The tools used in these laboratory activities were the same as those used for several previous decades, except for the addition of the digital stopwatch. Alcohol or mercury thermometers, triple-beam balances, meter sticks and rulers, graduated cylinders and spring scales. With this equipment, it was possible to collect data, but it was imprecise, and it was a time-consuming process.

Beginning in the 1990's and into the 2000s, companies began developing tools that would allow students to collect data using graphing calculators and computers. 
These tools were accurate and precise. They were easy to use and they were inexpensive enough that they could be purchased by schools.

About this same time, there was a push to add inquiry into the science classroom. Inquiry, paired with the ability to collect a lot of meaningful, accurate data quickly, meant that teachers could change the dynamics in their classrooms. They could move away from the traditional, lecture-lab-test format of teaching and move towards more active, engaging science learning. Students could begin to learn science by doing science.

There is not a great deal of research about using data collection technology in the secondary science classroom. There are, however, a large number of people that are using this technology to change the way they teach science. The anecdotal evidence and the popular literature support the use of this equipment to engage and excite students towards science.

In the first classroom study that was conducted here, the results suggest that there is an effect in using technology in the science classroom. The survey instrument showed a very small statistical affect, but the interviews conducted and the classroom observations seemed to suggest more. Students were animated about the lab work they were doing. They were beginning to see trends in their data and thinking about deeper meaning behind what they were doing.

However, the technology itself seemed to be getting in the way of more scientific learning. Some students became somewhat confused by the technology, spending time learning how to use the tools correctly. Other students spent mental energy and sometimes time trying to figure out how the technology did what it did. Both of these 
distractions kept the students from focusing on the science task at hand and instead kept them focused on the technology.

To avoid both of these distractions, the use of technology to collect data must begin before students reach the upper level science classes in high school. By beginning data collection early in high school, or even better, in middle school or upper elementary, would allow students to first of all, learn how to operate the equipment and become comfortable with it. Those students that are interested in learning how the technology works would also have ample opportunity to do so, both through simply using the tools, but also through experimentation with it and reading and asking questions about it. By the time a student enters a high school physics or chemistry class, the need to push forward with the material is so great that it becomes difficult for some teachers to set aside the time needed for the more basic familiarization activities that are required to remove both of these distractions.

An added benefit of beginning the use of data collection equipment early could also foster a richer ability by the students to engage in inquiry activities. This experience would foster a greater confidence in their abilities to use the data collection equipment successfully. A longer experience time also means they would be exposed to more of the individual probes that are used to measure different conditions. Because they would have been using the equipment for a longer period of time, they would be more familiar with it capabilities and could therefore design their own investigations more readily.

Another lesson from this research is that technology alone cannot reverse the attitudes of students towards science. There must also be a desire to learn within the student. The third study was very telling in this respect. The fact that there were two 
distinct groups of students with two distinct attitudes towards the class indicates this is so. The group of students assigned to the course seemed to begin the course with a negligent attitude and it persisted throughout the year. However, those that wanted to be in the class kept pushing themselves to learn, despite the fact that their learning was being impeded by the lack of progress being shown by the first group. Both groups experienced the same technology and classroom activities.

Technology is a tool. Just like any other tool. It does not possess of itself the ability to change a student's attitude towards a particular topic. It cannot create geniuses out of mediocre students. Technology is a tool. As a tool, it can be used by a skilled individual to perform a task. It can make that task easier. It can make the task more enjoyable. It can allow the person wielding the tool to do a task better than they could without it.

The job that data collection technology is best suited for is performing laboratory investigations. It makes it easier for students to collect and analyze their data. With this, it is possible for a talented teacher to inspire students to excel in science. Through the use of inquiry practices, students can be guided to ask their own questions about science and thereby build their own knowledge base.

Technology and inquiry must become a standard part of the secondary science classroom. Students must be exposed to data collection equipment early in their middle school careers and that experience must be built upon with each unit all the way through until high school. At that point, data must drive student learning. Students should be given probeware and shown how to ask their own scientific questions and how to answer 
those questions by designing investigations. They must be guided in how to use technology to collecting and analyzing data to answer those questions.

The driving force behind increasing student performance in science education should not be something that the teacher does, but rather something that the teacher enables the students to do. The greatest change in how to move science education forward needs to come from the students themselves. They must be allowed to construct their own knowledge. The best was to do that in science is to make them a part of the process. Students have to "do" science. Probeware and other technology is how this is going to be done.

\section{Suggestions for Further Studies}

While this study came to no definitive conclusion, it did suggest several avenues for future exploration. First, I would like to investigate the suggestion that data collection technology be introduced at an earlier level in a student's school career. I would like to find a teacher or group of teachers at the middle school level that are using or would implement the use of probeware and administer an attitude survey to those students. I would also administer the survey to a group of student that are not using probeware. Then, follow those students through their education career through $12^{\text {th }}$ grade, administering surveys to the students periodically, but especially in the last science course that they take in high school. Then, I would like to correlate the results with the amount of time they spent using probeware in their science courses.

Another study would be to find a cohort of math and science teachers that would be willing to team teach with graphing calculators and probeware. The science classes would be collecting the data, the math classes would be analyzing it for relationships and 
both would be guiding students in constructing critical thinking and scientific knowledge. Along with this, track student attitudes towards their learning in both math and science. Then, longitudinally track those attitudes as they progress through high school, again relating it to their use of probeware in their science classes.

I plan to continue using probeware in my science classes, expanding their use into as many areas as I can. I will also be looking at how the use of probeware improves student performance, possibly going back into my high school's Michigan Merit Exam and ACT data and correlate that data to probeware use. 


\section{References}

Apel, K., Gastineau, J., Bakken, C., \& Vernier, D. (2007). Physics with Vernier. Beaverton, Oregon: Vernier Software \& Technology. Retrieved from http://www.vernier.com

Coe, R. (2002). It's the Effect Size, Stupid. Retrieved February 8, 2012, from http://www.leeds.ac.uk/educol/documents/00002182.htm

Guskey, T. (2012). Mastery Learning | Education.com. Retrieved June 12, 2012, from http://www.education.com/reference/article/mastery-learning/

Hofstein, A., \& Lunetta, V. N. (2004). The laboratory in science education: Foundations for the twenty-first century. Science Education, 88(1), 28-54. doi:10.1002/sce.10106

Holmquist, D. D., Randall, J., \& Volz, D. L. (2007). Chemistry with Vernier. Beaverton, Oregon: Vernier Software and Technology. Retrieved from http://www.vernier.com

Keller, J. M. (2006). Motivation Design. Retrieved June 12, 2012, from http://www.arcsmodel.com/Mot dsgn.htm

Keller, J. M. (2010). Motivational design for learning and performance: The ARCS model approach. (p. 283). New York: Springer.

Kind, P., Jones, K., \& Barmby, P. (2007). Developing Attitudes towards Science Measures. International Journal of Science Education, 29(7), 871-893. doi:10.1080/09500690600909091

Learning Theories Knowledgebase. (2012). ARCS Model of Motivational Design (Keller) | Learning Theories. Retrieved June 12, 2012, from http://www.learningtheories.com/kellers-arcs-model-of-motivational-design.html

Linn, M. (2003). Technology and science education: Starting points, research programs, and trends. International Journal of Science Education, 25(6), 727-758. doi:10.1080/09500690305017

MIT Media Lab. (2003). Technological Fluency. Retrieved June 12, 2012, from http://llk.media.mit.edu/projects/clubhouse/research/handouts/fluency-v3.pdf

Metcalf, S. J., \& Tinker, R. F. (2004). Probeware and Handhelds in Elementary and Middle School Science. Journal of Science Education and Technology, 13(1), 43-49. 
Michigan Department of Education. (2006). Physics High School Content Expectations. Lansing, Michigan. Retrieved from http://www.michigan.gov/documents/Physics_HSCE_168208_7.pdf

National Research Council. (1996). National Science Education Standards. Wachington, D.C.: National Academies Press.

National Research Council. (2012). A Framework for K-12 Science Education. APS March Meeting Abstracts (p. 11). Washington, D.C.: National Academies Press. Retrieved from http://adsabs.harvard.edu/abs/2012APS..MAR.J2001Q

Phillips, D. C. (2000). Ninety-ninth Yearbook of the National Society for the Study of Education. Chicago, Il: Humana Press. Retrieved from $\mathrm{http}: / /$ books.google.com/books?id=sGtuBauW6LwC\&pgis=1

Solvie, P., \& Kloek, M. (2007). Using Technology Tools to Engage Students with Multiple Learning Styles in a Constructivist Learning Environment. Teacher, 7(2), 7-27. Retrieved from http://search.ebscohost.com/login.aspx?direct=true\&db=psyh\&AN=2007-15160$001 \&$ loginpage $=$ Login. asp\&site $=$ ehost-live $\&$ scope $=$ site

Thalheimer, W., \& Cook, S. (2002). How to calculate effect sizes from published research : A simplified methodology How to calculate effect sizes from published research articles :, (August).

Yerrick, R., \& Johnson, J. (2009). Meeting the Needs of Middle Grade Science Learners Through Pedagogical and Technological Intervention. Contemporary Issues in Technology and Teacher Education, 9(3), 280-315. Retrieved from http://www.citejournal.org/vol9/iss3/science/article1.cfm 


\section{Appendix A: Survey Instrument for Studies 1 \& 2}

Table 3: Survey Instrument for Studies 1 \& 2

\begin{tabular}{|c|c|c|c|c|c|}
\hline & $\begin{array}{l}\text { Strongly } \\
\text { Disagree }\end{array}$ & Disagree & $\begin{array}{l}\text { Undecid } \\
\text { ed }\end{array}$ & Agree & $\begin{array}{l}\text { Strongly } \\
\text { Agree }\end{array}$ \\
\hline We learn interesting things in science lessons. & 1 & 2 & 3 & 4 & 5 \\
\hline I look forward to my science lessons. & 1 & 2 & 3 & 4 & 5 \\
\hline $\begin{array}{l}\text { I like science better than most other subjects } \\
\text { at school. }\end{array}$ & 1 & 2 & 3 & 4 & 5 \\
\hline Science is boring. & 1 & 2 & 3 & 4 & 5 \\
\hline I find science difficult. & 1 & 2 & 3 & 4 & 5 \\
\hline I get good grades in science. & 1 & 2 & 3 & 4 & 5 \\
\hline I learn science quickly & 1 & 2 & 3 & 4 & 5 \\
\hline Science is one of my best subjects. & 1 & 2 & 3 & 4 & 5 \\
\hline \multirow[t]{2}{*}{ I feel helpless when doing science. } & 1 & 2 & 3 & 4 & 5 \\
\hline & $\begin{array}{l}\text { Strongly } \\
\text { Disagree }\end{array}$ & Disagree & $\begin{array}{l}\text { Undecid } \\
\text { ed }\end{array}$ & Agree & $\begin{array}{l}\text { Strongly } \\
\text { Agree }\end{array}$ \\
\hline Lab work in science is interesting. & 1 & 2 & 3 & 4 & 5 \\
\hline $\begin{array}{l}\text { I like science lab work because you don't } \\
\text { know what will happen. }\end{array}$ & 1 & 2 & 3 & 4 & 5 \\
\hline $\begin{array}{l}\text { Lab work in science is good because I can } \\
\text { work with my friends. }\end{array}$ & 1 & 2 & 3 & 4 & 5 \\
\hline $\begin{array}{l}\text { I like lab work in science because I can decide } \\
\text { what to do myself. }\end{array}$ & 1 & 2 & 3 & 4 & 5 \\
\hline $\begin{array}{l}\text { I would like more lab work in my science } \\
\text { lessons. }\end{array}$ & 1 & 2 & 3 & 4 & 5 \\
\hline We learn science better when we do lab work. & 1 & 2 & 3 & 4 & 5 \\
\hline I look forward to doing science labs. & 1 & 2 & 3 & 4 & 5 \\
\hline \multirow[t]{2}{*}{ Lab work in science is boring. } & 1 & 2 & 3 & 4 & 5 \\
\hline & $\begin{array}{l}\text { Strongly } \\
\text { Disagree }\end{array}$ & Disagree & $\begin{array}{l}\text { Undecid } \\
\text { ed }\end{array}$ & Agree & $\begin{array}{l}\text { Strongly } \\
\text { Agree }\end{array}$ \\
\hline I like watching science shows on TV. & 1 & 2 & 3 & 4 & 5 \\
\hline I like to visit science museums. & 1 & 2 & 3 & 4 & 5 \\
\hline $\begin{array}{l}\text { I would like to do more science activities } \\
\text { outside of school. }\end{array}$ & 1 & 2 & 3 & 4 & 5 \\
\hline I like reading science magazines and books. & 1 & 2 & 3 & 4 & 5 \\
\hline $\begin{array}{l}\text { It is exciting to learn about new things } \\
\text { happening in science. }\end{array}$ & 1 & 2 & 3 & 4 & 5 \\
\hline $\begin{array}{l}\text { I would like to study more science in the } \\
\text { future. }\end{array}$ & 1 & 2 & 3 & 4 & 5 \\
\hline \multirow[t]{2}{*}{ I would like a job working with science. } & 1 & 2 & 3 & 4 & 5 \\
\hline & $\begin{array}{l}\text { Strongly } \\
\text { Disagree }\end{array}$ & Disagree & $\begin{array}{l}\text { Undecid } \\
\text { ed }\end{array}$ & Agree & $\begin{array}{l}\text { Strongly } \\
\text { Agree }\end{array}$ \\
\hline $\begin{array}{l}\text { Science and technology are important for } \\
\text { society. }\end{array}$ & 1 & 2 & 3 & 4 & 5 \\
\hline $\begin{array}{l}\text { Science and technology make our lives easier } \\
\text { and more comfortable. }\end{array}$ & 1 & 2 & 3 & 4 & 5 \\
\hline Science and technology are helping the poor. & 1 & 2 & 3 & 4 & 5 \\
\hline Scientists have exciting jobs. & 1 & 2 & 3 & 4 & 5 \\
\hline
\end{tabular}




\begin{tabular}{|c|c|c|c|c|c|}
\hline & $\begin{array}{l}\text { Strongly } \\
\text { Disagree }\end{array}$ & Disagree & $\begin{array}{l}\text { Undecid } \\
\text { ed }\end{array}$ & Agree & $\begin{array}{c}\text { Strongly } \\
\text { Agree }\end{array}$ \\
\hline I really like school. & 1 & 2 & 3 & 4 & 5 \\
\hline I find school boring. & 1 & 2 & 3 & 4 & 5 \\
\hline I get along well with most of my teachers. & 1 & 2 & 3 & 4 & 5 \\
\hline I am normally happy when I am in school. & 1 & 2 & 3 & 4 & 5 \\
\hline \multirow[t]{2}{*}{ I work as hard as I can in school. } & 1 & 2 & 3 & 4 & 5 \\
\hline & $\begin{array}{l}\text { Strongly } \\
\text { Disagree }\end{array}$ & Disagree & $\begin{array}{c}\text { Undecid } \\
\text { ed }\end{array}$ & Agree & $\begin{array}{c}\text { Strongly } \\
\text { Agree }\end{array}$ \\
\hline I am comfortable using computers. & 1 & 2 & 3 & 4 & 5 \\
\hline I am comfortable using graphing calculators. & 1 & 2 & 3 & 4 & 5 \\
\hline I enjoy using technology in science. & 1 & 2 & 3 & 4 & 5 \\
\hline It is important to use technology in science. & 1 & 2 & 3 & 4 & 5 \\
\hline I wish we used more technology in science. & 1 & 2 & 3 & 4 & 5 \\
\hline
\end{tabular}




\section{Appendix B: Interview Questions for Studies 1 \& 2}

\section{Summer Camp Interviews}

1. What did you learn from the ecosystem lesson?

2. What was your favorite part about the ecosystem lesson?

3. What was your least favorite part of the lesson?

4. How do you use computers at home?

5. How do you use computers at school?

6. Did you enjoy using the calculator and probe to take measurements?
a. Why/why not?

7. How would you make this lesson better?

\section{Formal Class Interviews}

1. What did you learn from using graphing calculators and probeware in this class?

2. What was your favorite part about using graphing calculators and probes?

3. What was your least favorite part of the class?

4. How do you use computers at home?

5. How do you use computers at school?

6. Did you enjoy using the calculator and probe to take measurements?

a. Why/why not?

7. How would you make this class better? 


\section{Appendix C: ARCS Survey Instrument for Study 3}

Please mark your answer sheet in accordance to the scale listed under each question. "A" for not true and "E" for very true.

1. When I first heard about this course, I had the impression that it would be easy for me.

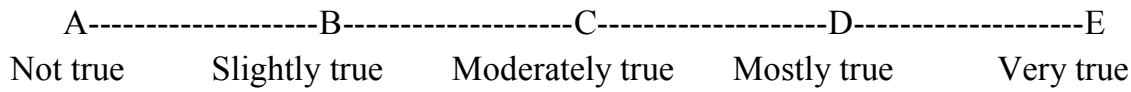

2. There was something interesting at the beginning of this course that captured my attention.

Not true Slightly true Moderately true Mostly true $\quad$ Very true

3. This course seems more difficult to understand than I would like for it to be.

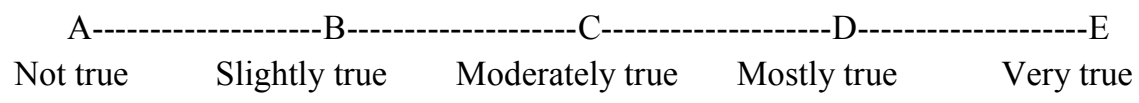

4. Completing this course will give me a satisfying feeling of accomplishment.

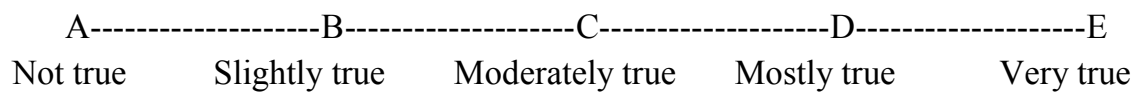

5. It is clear to me how this course is related to things I already know.

Not true Slightly true Moderately true Mostly true

6. There appears to be so much information in this course that it would be hard for me to pick out and remember the important points.

\begin{tabular}{|c|c|c|}
\hline & ----------B---. & 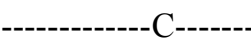 \\
\hline Tot true & Slightly true & Moderately true \\
\hline
\end{tabular}

7. This course gains and sustains my attention.

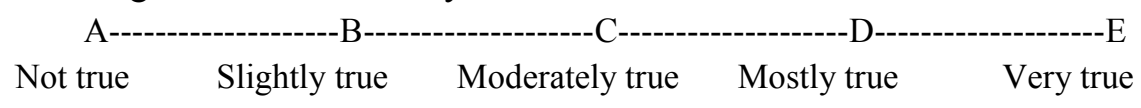

8. The materials contained in this course are important to me and relevant to my future.

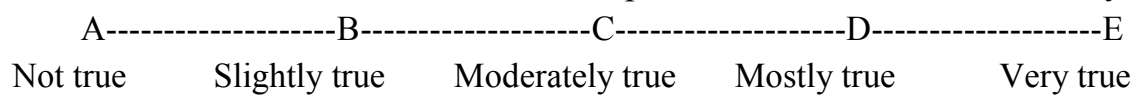

9. Completing this course successfully is important to me.

Not true Slightly true Moderately true Mostly true


10. The quality of this course helps to hold my attention.

Not true Slightly true Moderately true Mostly true $\quad$ Very true

11. This course appears to be so abstract that it will be hard to keep my attention on it.

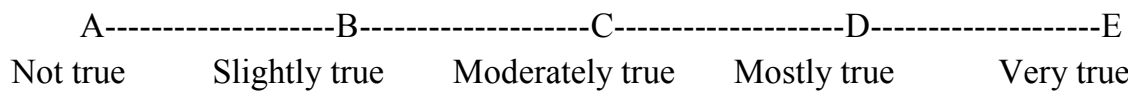

12. As I progressed through the course, I felt more confident that I could learn the content.

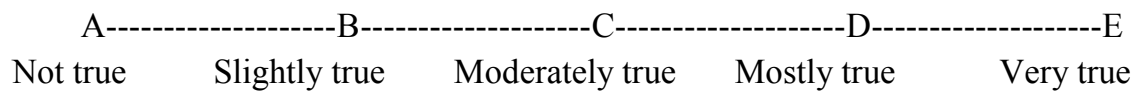

13. I enjoy this course so much that I would like to know more about this topic.

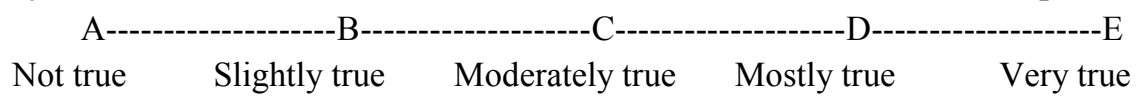

14. The course is dry and unappealing.

Not true Slightly true Moderately true Mostly true $\quad$ Very true

15. The course is relevant to my needs and interests.

Not true Slightly true Moderately true Mostly true $\quad$ Very true

16. The way this course is designed helps keep my attention.

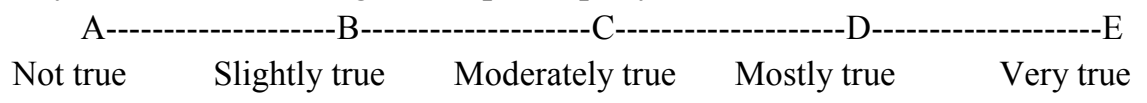

17. It is already apparent to me how people use the knowledge in this course.

Not true Slightly true Moderately true Mostly true $\quad$ Very true

18. This course is too difficult.

A-----------B-------------C------------D--------------E
Not true Slightly true Moderately true

19. This course has things that stimulate my curiosity.

Not true Slightly true Moderately true Mostly true

20. I enjoy studying this course.

Not true Slightly true Moderately true Mostly true $\quad$ Very true


21. The amount of repetition in this course causes me to get bored sometimes.

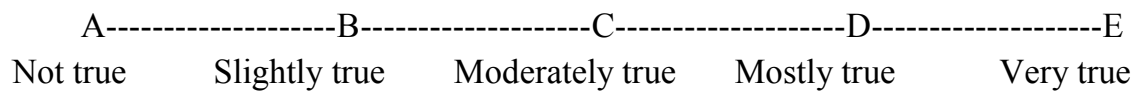

22. The contents of this course are worth knowing.

Not true Slightly true Moderately true Mostly true $\quad$ Very true

23. I learned something surprising or unexpected in this course.

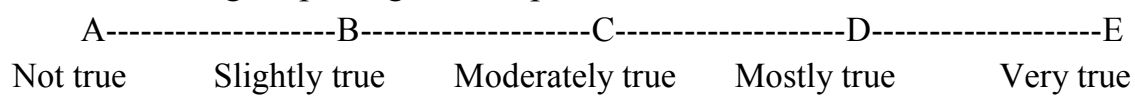

24. After working on this course for a while, I am confident in my ability to successfully complete all course assignments and requirements.

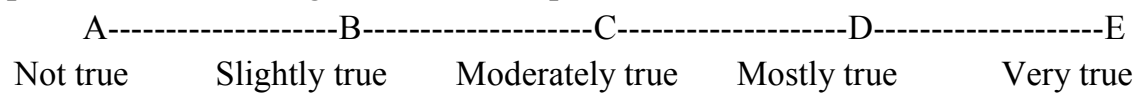

25. This course is not relevant to my needs because I already knew most of it.

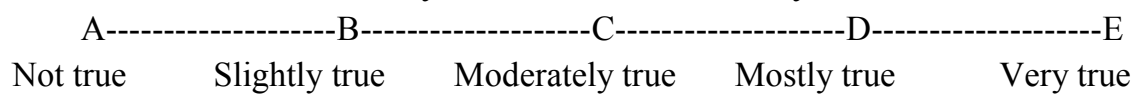

26. The wording of feedback after assignments, or of other comments in this course helped me feel rewarded for my efforts.

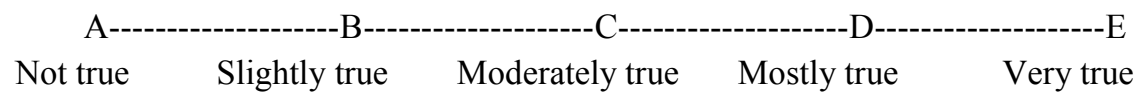

27. The variety of reading materials, exercises, illustration, etc., helps keep my attention on the course.

Not true Slightly true Moderately true Mostly true $\quad$ Very true

28. The data collection technology used in this course helps me understand the material in more detail.

Not true Slightly true Moderately true Mostly true $\quad$ Very true

29. The graphing calculators used in this course help me understand the material in more detail.

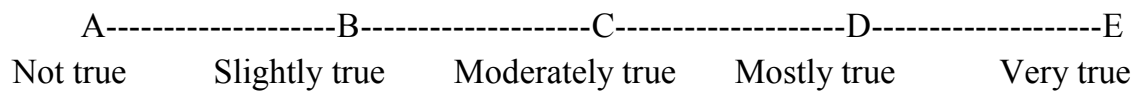

30. This course is boring.

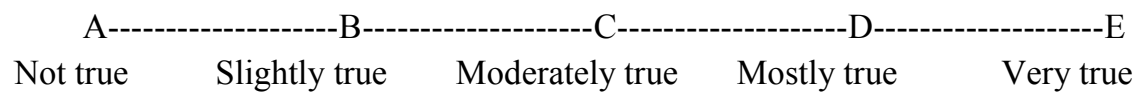


31. I am able to relate the contents of this course to things I have seen, done, or thought about in my own life.

Not true Slightly true Moderately true Mostly true $\quad$ Very true

32. The technology used in this course is frustrating/irritating.

Not true Slightly true Moderately true Mostly true $\quad$ Very true

33. There are too many assignments and activities in this course that I feel are not worth completing.

Not true Slightly true Moderately true Mostly true $\quad$ Very true

34. The assignments in this course are useful to me and are worth completing.

Not true Slightly true Moderately true Mostly true $\quad$ Very true

35. I do not really understand quite a bit of the material in this course.

Not true Slightly true Moderately true Mostly true $\quad$ Very true

36. The organization of this course helps build my confidence in learning the material.

Not true Slightly true Moderately true Mostly true $\quad$ Very true

37. The skills and knowledge that I'm gaining from this course are worth the time and effort that I am putting into the course.

Not true Slightly true Moderately true Mostly true $\quad$ Very true




\section{Appendix D: Effect size results for Study 1}

Table 4: Effect Size results for Study 1

\begin{tabular}{|c|c|c|c|c|}
\hline Question & $\begin{array}{c}\text { Pre-Test } \\
\text { Mean } \\
n=6\end{array}$ & $\begin{array}{c}\text { Post-Test } \\
\text { Mean } \\
n=6\end{array}$ & Change & $\begin{array}{c}\text { Effect } \\
\text { Size }\end{array}$ \\
\hline We learn interesting things in science lessons. & 4.40 & 4.80 & 0.40 & 0.81 \\
\hline I look forward to my science lessons. & 4.00 & 4.40 & 0.40 & 0.49 \\
\hline I like science better than most other subjects at school. & 3.60 & 4.60 & 1.00 & 0.94 \\
\hline Science is boring. & 1.80 & 1.60 & 0.20 & -0.24 \\
\hline I find science difficult. & 2.40 & 2.60 & -0.20 & 0.21 \\
\hline I get good grades in science. & 4.20 & 4.80 & 0.60 & 0.59 \\
\hline I learn science quickly & 4.00 & 3.80 & -0.20 & -0.18 \\
\hline Science is one of my best subjects. & 4.20 & 4.80 & 0.60 & 0.59 \\
\hline I feel helpless when doing science. & 1.40 & 1.80 & -0.40 & 0.39 \\
\hline Lab work in science is interesting. & 4.80 & 4.60 & -0.20 & -0.42 \\
\hline $\begin{array}{r}\text { I like science lab work because you don't know what will } \\
\text { happen. }\end{array}$ & 3.60 & 3.80 & 0.20 & 0.17 \\
\hline $\begin{array}{r}\text { Lab work in science is good because I can work with my } \\
\text { friends. }\end{array}$ & 3.00 & 3.20 & 0.20 & 0.12 \\
\hline $\begin{array}{r}\text { I like lab work in science because I can decide what to do } \\
\text { myself. }\end{array}$ & 3.80 & 4.20 & 0.40 & 0.41 \\
\hline I would like more lab work in my science lessons. & 3.80 & 4.00 & 0.20 & 0.17 \\
\hline We learn science better when we do lab work. & 2.80 & 3.80 & 1.00 & 0.73 \\
\hline I look forward to doing science labs. & 4.60 & 4.20 & -0.40 & -0.61 \\
\hline Lab work in science is boring. & 1.00 & 1.80 & -0.80 & 1.21 \\
\hline I like watching science shows on TV. & 3.40 & 3.40 & 0.00 & 0.00 \\
\hline I like to visit science museums. & 4.20 & 3.60 & -0.60 & -0.58 \\
\hline $\begin{array}{r}\text { I would like to do more science activities outside of } \\
\text { school. }\end{array}$ & 4.40 & 3.60 & -0.80 & -0.76 \\
\hline I like reading science magazines and books. & 3.40 & 3.40 & 0.00 & 0.00 \\
\hline $\begin{array}{r}\text { It is exciting to learn about new things happening in } \\
\text { science. }\end{array}$ & 3.60 & 4.00 & 0.40 & 0.44 \\
\hline I would like to study more science in the future. & 4.40 & 4.20 & -0.20 & -0.24 \\
\hline I would like a job working with science. & 4.00 & 3.80 & -0.20 & -0.20 \\
\hline Science and technology are important for society. & 4.40 & 4.80 & 0.40 & 0.55 \\
\hline $\begin{array}{r}\text { Science and technology make our lives easier and more } \\
\text { comfortable. }\end{array}$ & 4.20 & 4.20 & 0.00 & 0.00 \\
\hline Science and technology are helping the poor. & 3.20 & 3.80 & 0.60 & 0.53 \\
\hline Scientists have exciting jobs. & 4.40 & 4.40 & 0.00 & 0.00 \\
\hline I really like school. & 2.80 & 3.00 & 0.20 & 0.13 \\
\hline I find school boring. & 2.80 & 3.00 & -0.20 & 0.14 \\
\hline I get along well with most of my teachers. & 3.60 & 3.80 & 0.20 & 0.17 \\
\hline I am normally happy when I am in school. & 3.20 & 3.20 & 0.00 & 0.00 \\
\hline
\end{tabular}




\begin{tabular}{|r|c|c|c|c|}
\hline I work as hard as I can in school. & 3.60 & 4.00 & 0.40 & 0.67 \\
\hline I am comfortable using computers. & 4.80 & 4.80 & 0.00 & 0.00 \\
\hline I am comfortable using graphing calculators. & 3.80 & 4.20 & 0.40 & 0.38 \\
\hline I enjoy using technology in science. & 4.40 & 4.40 & 0.00 & 0.00 \\
\hline It is important to use technology in science. & 4.60 & 4.20 & -0.40 & -0.45 \\
\hline I wish we used more technology in science. & 4.20 & 4.40 & 0.20 & 0.20 \\
\hline Overall & $\mathbf{3 . 6 5}$ & $\mathbf{3 . 8 2}$ & $\mathbf{0 . 0 9}$ & $\mathbf{0 . 1 7}$ \\
\hline
\end{tabular}




\section{Appendix E: Effect size results for Study 2}

Table 5: Effect Size Results for Study 2

\begin{tabular}{|c|c|c|c|c|}
\hline Question & $\begin{array}{c}\text { Pre- } \\
\text { Test } \\
\text { Mean } \\
n=58\end{array}$ & $\begin{array}{c}\text { Post- } \\
\text { Test } \\
\text { Mean } \\
n=52\end{array}$ & Change & $\begin{array}{l}\text { Effect } \\
\text { Size }\end{array}$ \\
\hline We learn interesting things in science lessons. & 3.83 & 3.92 & 0.10 & 0.11 \\
\hline I look forward to my science lessons. & 3.29 & 3.38 & 0.09 & 0.08 \\
\hline I like science better than most other subjects at school. & 3.03 & 3.21 & 0.18 & 0.14 \\
\hline Science is boring. & 2.24 & 2.27 & 0.03 & 0.03 \\
\hline I find science difficult. & 2.81 & 2.71 & -0.10 & -0.09 \\
\hline I get good grades in science. & 3.66 & 3.67 & 0.02 & 0.02 \\
\hline I learn science quickly & 3.02 & 3.29 & 0.27 & 0.23 \\
\hline Science is one of my best subjects. & 2.98 & 3.35 & 0.36 & 0.29 \\
\hline I feel helpless when doing science. & 2.29 & 1.94 & -0.35 & -0.33 \\
\hline Lab work in science is interesting. & 4.07 & 3.92 & -0.15 & -0.15 \\
\hline $\begin{array}{r}\text { I like science lab work because you don't know what will } \\
\text { happen. }\end{array}$ & 3.81 & 3.81 & 0.00 & 0.00 \\
\hline $\begin{array}{r}\text { Lab work in science is good because I can work with my } \\
\text { friends. }\end{array}$ & 3.89 & 3.85 & -0.05 & -0.05 \\
\hline $\begin{array}{r}\text { I like lab work in science because I can decide what to do } \\
\text { myself. }\end{array}$ & 3.52 & 3.41 & -0.11 & -0.09 \\
\hline I would like more lab work in my science lessons. & 3.86 & 3.90 & 0.04 & 0.04 \\
\hline We learn science better when we do lab work. & 3.91 & 3.75 & -0.16 & -0.16 \\
\hline I look forward to doing science labs. & 4.05 & 3.91 & -0.14 & -0.14 \\
\hline Lab work in science is boring. & 1.71 & 1.71 & 0.00 & 0.01 \\
\hline I like watching science shows on TV. & 3.36 & 3.33 & -0.04 & -0.03 \\
\hline I like to visit science museums. & 3.16 & 3.29 & 0.13 & 0.11 \\
\hline $\begin{array}{r}\text { I would like to do more science activities outside of } \\
\text { school. }\end{array}$ & 2.97 & 3.17 & 0.21 & 0.18 \\
\hline I like reading science magazines and books. & 2.50 & 2.75 & 0.25 & 0.22 \\
\hline $\begin{array}{r}\text { It is exciting to learn about new things happening in } \\
\text { science. }\end{array}$ & 3.60 & 3.56 & -0.05 & -0.04 \\
\hline I would like to study more science in the future. & 3.28 & 3.43 & 0.16 & 0.13 \\
\hline I would like a job working with science. & 2.96 & 3.12 & 0.15 & 0.13 \\
\hline Science and technology are important for society. & 4.47 & 4.38 & -0.08 & -0.10 \\
\hline $\begin{array}{r}\text { Science and technology make our lives easier and more } \\
\text { comfortable. }\end{array}$ & 4.47 & 4.37 & -0.10 & -0.13 \\
\hline Science and technology are helping the poor. & 3.12 & 3.44 & 0.32 & 0.31 \\
\hline Scientists have exciting jobs. & 3.78 & 3.65 & -0.12 & -0.13 \\
\hline I really like school. & 3.07 & 3.17 & 0.10 & 0.08 \\
\hline
\end{tabular}




\begin{tabular}{|r|c|c|c|c|}
\hline I find school boring. & 2.95 & 2.96 & 0.01 & 0.01 \\
\hline I get along well with most of my teachers. & 4.29 & 4.06 & -0.24 & -0.26 \\
\hline I am normally happy when I am in school. & 3.72 & 3.62 & -0.11 & -0.10 \\
\hline I work as hard as I can in school. & 3.78 & 3.58 & -0.20 & -0.19 \\
\hline I am comfortable using computers. & 4.31 & 4.08 & -0.23 & -0.26 \\
\hline I am comfortable using graphing calculators. & 3.98 & 3.83 & -0.16 & -0.14 \\
\hline I enjoy using technology in science. & 3.88 & 3.81 & -0.07 & -0.07 \\
\hline It is important to use technology in science. & 4.09 & 4.08 & -0.01 & -0.01 \\
\hline I wish we used more technology in science. & 3.57 & 3.58 & 0.01 & 0.01 \\
\hline Overall & $\mathbf{3 . 4 5}$ & $\mathbf{3 . 4 5}$ & $\mathbf{0 . 0 0}$ & $\mathbf{0 . 0 0}$ \\
\hline
\end{tabular}




\section{Appendix F: Study 2 Interview Transcripts}

\section{Question 1: What did you learn from using graphing calculators and probeware in this class?}

Stephanie: We hooked up the probeware to the LabPro and we had a car running through and we were measuring them. We were measuring, I can't really remember it but I can describe it. We have it set on there and we were running the cart towards it, and away from it. I would have to say we were measuring speed or acceleration.

Jessica: I learned the comparison between velocity and ..... Because when I was standing in front of the probeware and jumping up and down it didn't change it but when I moved back and forth it did. I learned about the force probes. I am still working with those. Fun to use. The cars with the sensors. I remember using them and it was pretty interesting how the different angles would change the speed of the car.

Austin: I learned about the LabPro and how to plug the calculator in and how to go up to the apps and use the Easy Data charts and I learned about time graph table and graphing and whatnot and I learned what that meant like if your horizontal was time and your vertical was like how fast it was going and I learned how to read those. We were using accelerometers and we were using accelerometers and a ramp and we had a photogate. When it went past a photogate and it would collect all our data for us and we would analyze it and answer all of our questions.

From those labs I learned more about friction and forces going against objects. I learned about things you couldn't control. I learned that depending on how high your ramp is the faster your object will go. 
Meagan: I learned that using the technology can be more accurate than using ourselves and using the calculators you can save things that you can compare later. Doing $\mathrm{pH}$ balances which is acids and bases.

\section{Question 2: What was your favorite part about using graphing calculators and probes?}

Stephanie: I like using a lot of technology. A lot of the fun for me is figuring out how it works, which I really couldn't do with the probeware. We were doing something and we had lots of different systems set up, the Atwood's Machine in the last project and we just had all sorts of things hooked up to everywhere, and I was just trying to figure how everything worked. I was trying to remember if it was like a laser beam or whatever. The photogate. And the thing which I couldn't figure out with the wheel. If it is spinning so fast that it should just continue uninterrupted. So I was trying to figure out how that worked. So I guess that was the fun of it for me. I was trying to figure out how it all worked and how is it measuring the motion going back and forth because in my mind if it sitting right there, even if it is shooting off the sides it shouldn't show any motion because it is still sitting in the same place. I was just trying to figure that out.

Jessica: The calculator worked with them. Because I don't know the calculators

really well, the calculator helps me to understand it. I do simple math but when it comes to deep calculations it takes me a little while, like when you use the force probes and stuff. Taking down the information and knowing what I am taking down instead of just looking at the number and going... uh... read (them) right off. Being able to decipher what is going on. 
Austin: I've never used something like that before so just learning how that works. Also, that it can help you figure out compare two. Before you had hypotheses in your head about what could happen and this helped you see what actually happened.

Meagan: The fact that it told us what the answer was rather than us trying to figure it out and possible not being right. Like the $\mathrm{pH}$ balance if we had to do it ourselves without the probe thingy we would have probably be a little bit off or a lot off. With the probe, we had assurance that we had the right answer.

\section{Discussion}

Students seemed to trust the results they received by using the probeware more than they would if using analog equipment. They trusted the results despite the fact that the equipment was new to them and that, in general, they didn't understand how it worked.

Students also seemed to have a strong desire to understand how the equipment worked. This seemed to get in the way of the science for some of the students, as was apparent in some students' actions during the laboratory activities. Many students were so engrossed in the equipment and getting the settings right that they were not as focused on the science of the activity.

\section{Question 3: What was your least favorite part about using the technology?}

Stephanie: Doing the equations that we had to get when we gathered the information. Applying that into the actual equations.

Jessica: Probably the set up and getting the setup just the way it was supposed to be. I like using the force probes some of the things were frustrating getting the angles just right is still very difficult. 
Austin: When sometimes it didn't work and you had to figure out what the problem is.

Meagan: Not knowing how to work it properly. We need to be trained more before we go into the lab.

\section{Discussion}

The downside of the technology for the students was the lack of familiarity in how to set up the probeware and how to correct errors in the setup if there were problems. There was definitely a learning curve in the use of this type of equipment. When the student exposure level was low, they appeared to struggle with the equipment, but as they became more familiar with it, these difficulties appeared to lessen. This problem could be easily corrected if students were given more exposure to the digital data collection equipment. This ideally would occur gradually over the course of a student's school career, but could also be accomplished within one course, with more frequent lab activities.

This lack of familiarity could also be a contributing factor to the apparent decrease in agreement with the question "I am comfortable using graphing calculators." If students are given familiar equipment, the graphing calculator, and are asked to use it in a new way, for data collection, then their comfort level with that equipment may decrease.

\section{Question 4: How do you use computers at home?}

Stephanie: I use lots of computers at home. I use it for basic stuff like the internet and playing games and then I use it for other applications like Adobe Photoshop and 
Illustrator which I think is how I ended up making my Attwood's machine for my lab report which was on Photoshop I think.

Jessica: I use computers at home. Facebook and email. Simple documents like spreadsheets. Nothing real in depth.

Austin: I go on the internet and I type up essays and do PowerPoint on my computer. I play games and I use Excel on the computer. I burn music and I listen to music on the computer.

Meagan: Just to check emails and school stuff and to communicate with friends. IM and email and games.

\section{Discussion}

These students seemed to be fairly technologically literate. They were used to interacting with computers for various tasks, both school related and personal. A few of them were even what could be considered technologically fluent, according to the MIT Media Lab description (2003). However, this technological literacy did not mean that they were able to take this new technology and immediately apply it to their learning.

Students apparently needed ample opportunity to become familiar with these new applications of technology before they could assimilate them into their learning

processes. This seemed to be the case with those that could be considered technologically fluent and also with those that are not. Those that were fluent, like Austin, had a desire to understand how the technology worked. Those that were less fluent, like Meagan, had a more immediate desire to learn how to make the technology do what they wanted. 
The point is that there is a learning curve to all new technology for an individual. How steep that learning curve is may depend in part on the individual's technological fluency. We cannot assume that simply because a person is technologically fluent that they will immediately grasp how to use a new technology to learn science. They must be given the opportunity to become familiar with the new technology.

\section{Question 5: How do you use computers at school?}

Stephanie: Use them mostly for research except for right now I am taking a computer class so I am using them, you know, the same sort of programs I'm using at home: Adobe Photoshop and similar things to that. But mostly when I am in there I use Word, the Internet, (and) Google, looking up information and putting it into the document.

Jessica: Minimal. I don’t really use them very much. I use calculators more than I use computers right now.

Austin: I use the form PowerPoint presentation and in personal finance I use Excel for figuring profits and things.

Meagan: To do more research on things that I don't know so much about.

\section{Discussion}

Most student exposure to technology in school appeared to be in the form of Internet research and calculators. Technology did not appear to be truly integrated into the learning environment that these students were currently engaged in. It seemed to be a more superficial presence in their learning.

Using a graphing calculator to collect data goes beyond using a web browser to do research, or Microsoft PowerPoint or Word to present the data. It even goes beyond 
using a graphing calculator to solve a math problem. Data collection is a continuous, dynamic interaction between the user and the equipment. To introduce students to a new type of educational technology, especially one that requires a deeper interaction with the equipment, requires an opportunity for them to become more familiar with the technology.

\section{Question 6: Did you enjoy using the calculator and probe to take measurements? Why or why not?}

Stephanie: Yeah, because I don't have to do it manually.

If I didn't have these calculators I would have to learn more math which I am not favorable of. I don't like math very much. It is calculating things like showing us slopes

and, for graphs that we are doing. If we didn't have calculators I would have to do all of those graphs and figuring out the slopes instead of plotting out the graphs and it telling me. I guess the technology is I like figuring out how it is doing all of that. How the photogate is taking all of that and applying it and figuring all of this out.

It would have definitely taken me longer to do it without the calculator because, like I said, If we are doing the photogate sort of thing I would have to stop it at each point, find out where it is graph it, stop it again, graph it again, do that and the connect the dots do the slope intercept and find all of that out. Instead it just does all that and then says here's you graph, here's the information. I don't have to manually do that and take the time to plot each one and do all of the mathematics for the slope. It does it for me. 
Jessica: At the beginning no. At the end, more.

I didn't understand how to use the calculators at the beginning. I'm not real fast when it comes to using technology. But now after using it so much I am starting to get the hang of it and others are helping me out, too.

Austin: I enjoyed it. It was pretty good technology. It was better than what you guys used back in the days. It's stuff that we should actually be using.

Meagan: Yes and no. It was frustrating at first and hard to figure out. But after we worked with it I got used to it and I liked learning how to do things that I didn't know how to do.

\section{Discussion}

Students responded favorably to the use of technology, mostly because of how it made the job of data collection easier and less tedious. This was especially an aid to those students that may have struggled with mathematics, as it gave them another tool to support their learning in that area. The fact that the calculator can perform some of these tasks, like finding the equation of a line represented by the data, can help students get beyond their deficiencies in math and learn the science behind the relationships.

Students continued to express a concern over the learning curve required to effectively use the equipment, though. How can a lesson or an entire course be structured to provide the technology that helps a student's understanding of science but yet also provide enough scaffolding to build their comfort with that technology? Also, how do you bring the math back into the picture for those students that are weak in that area? To fully understand the science a person must also understand the math. 


\section{Question 7: How would you make the labs better?}

Stephanie: That one is really hard. I am thinking of the ones we did with all the I'm remembering the three labs really clearly are the Attwood's machine, the one were we were using the cart on the wood and setting it up from there and then the one, where we're messing around with them and walking back and forth in front of the. I can't remember any specific thing...I guess one of the things were when we figuring out acceleration we had to stop it before it would fall off the tracks and I guess I don't understand why that was something that we had to do. I guess that one was somewhat confusing for me just because I didn't understand how it was measuring acceleration when it was sitting horizontal from it rather than vertically. I could understand if was sitting vertically you can have the measurements and calculate that, but horizontally ... it was just moving away from it... that was kind of confusing to me so when it came to the end of the track we had to grab it with our hands or else it would mess up the data.

Jessica: Step by step procedure of exactly what to do. I don't know. I like the way we use them now. The freedom is nice, it's just the setup is a little hard.

Freedom. You didn't give us a set procedure. I like the step-by step but I also like to be able to do it yourself instead of the step by step, hold your hand the entire way.

Austin: I don't know. Maybe if we did more experiments. We could use different objects than just the cart. Maybe a ball or a different cart or something else.

Meagan: To do a self-demonstration before we go into the lab to make sure we all know what we were doing. 


\section{Appendix G: Average Responses for Study 3}

Analysis for questions 3, 6, 11, 14, 18, 21, 25, 30, 32, 33, and 35 are not included as the negative wording of these questions was determined to be confusing, based on correlation with similar questions.

Table 6: Average Responses for Study 3

\begin{tabular}{|c|c|c|}
\hline & Question & $\begin{array}{c}\text { Average } \\
\text { Response } \\
n=14\end{array}$ \\
\hline 1 & When I first heard about this course, I had the impression that it would be easy for me. & 2.0 \\
\hline 2 & $\begin{array}{l}\text { There was something interesting at the beginning of this course that captured my } \\
\text { attention. }\end{array}$ & 2.4 \\
\hline 3 & This course seems more difficult to understand than I would like for it to be. & \\
\hline 4 & Completing this course will give me a satisfying feeling of accomplishment. & 2.9 \\
\hline 5 & It is clear to me how this course is related to things I already know. & 2.9 \\
\hline 6 & $\begin{array}{l}\text { There appears to be so much information in this course that it would be hard for me } \\
\text { to pick out and remember the important points. }\end{array}$ & \\
\hline 7 & This course gains and sustains my attention. & 1.9 \\
\hline 8 & The materials contained in this course are important to me and relevant to my future. & 2.2 \\
\hline 9 & Completing this course successfully is important to me. & 3.6 \\
\hline 10 & The quality of this course helps to hold my attention. & 2.2 \\
\hline 11 & This course appears to be so abstract that it will be hard to keep my attention on it. & \\
\hline 12 & $\begin{array}{l}\text { As I progressed through the course, I felt more confident that I could learn the } \\
\text { content. }\end{array}$ & 2.4 \\
\hline 13 & I enjoy this course so much that I would like to know more about this topic. & 2.0 \\
\hline 14 & The course is dry and unappealing. & \\
\hline 15 & The course is relevant to my needs and interests. & 2.0 \\
\hline 16 & The way this course is designed helps keep my attention. & 1.9 \\
\hline 17 & It is already apparent to me how people use the knowledge in this course. & 2.9 \\
\hline
\end{tabular}




\begin{tabular}{|c|c|c|}
\hline 18 & This course is too difficult. & \\
\hline 19 & This course has things that stimulate my curiosity. & 2.5 \\
\hline 20 & I enjoy studying this course. & 2.5 \\
\hline 21 & The amount of repetition in this course causes me to get bored sometimes. & \\
\hline 22 & The contents of this course are worth knowing. & 3.0 \\
\hline 23 & I learned something surprising or unexpected in this course. & 2.6 \\
\hline 24 & $\begin{array}{l}\text { After working on this course for a while, I am confident in my ability to successfully } \\
\text { complete all course assignments and requirements. }\end{array}$ & 2.4 \\
\hline 25 & This course is not relevant to my needs because I already knew most of it. & \\
\hline 26 & $\begin{array}{l}\text { The wording of feedback after assignments, or of other comments in this course } \\
\text { helped me feel rewarded for my efforts. }\end{array}$ & 2.6 \\
\hline 27 & $\begin{array}{l}\text { The variety of reading materials, exercises, illustration, etc., helps keep my attention } \\
\text { on the course. }\end{array}$ & 2.5 \\
\hline 28 & $\begin{array}{l}\text { The data collection technology used in this course helps me understand the material in } \\
\text { more detail. }\end{array}$ & 2.6 \\
\hline 29 & $\begin{array}{l}\text { The graphing calculators used in this course help me understand the material in more } \\
\text { detail. }\end{array}$ & 2.6 \\
\hline 30 & This course is boring. & \\
\hline 31 & $\begin{array}{l}\text { I am able to relate the contents of this course to things I have seen, done, or thought } \\
\text { about in my own life. }\end{array}$ & 2.9 \\
\hline 32 & The technology used in this course is frustrating/irritating. & \\
\hline 33 & $\begin{array}{l}\text { There are too many assignments and activities in this course that I feel are not worth } \\
\text { completing. }\end{array}$ & \\
\hline 34 & The assignments in this course are useful to me and are worth completing. & 2.7 \\
\hline 35 & I do not really understand quite a bit of the material in this course. & \\
\hline 36 & The organization of this course helps build my confidence in learning the material. & 2.5 \\
\hline 37 & $\begin{array}{l}\text { The skills and knowledge that I'm gaining from this course are worth the time and } \\
\text { effort that I am putting into the course. }\end{array}$ & 2.7 \\
\hline
\end{tabular}




\title{
Appendix H: Student Investigation
}

\section{Centripetal Acceleration at the Playground}

\author{
Krystyne x. Xxxxx \\ Zach Xxxx, Jacob Xxxxxx
}

May 23, 2010

Mr. Damery

\begin{abstract}
At the playground, swings are an excellent example of changing acceleration along a circular path, otherwise known as centripetal acceleration. We will study how centripetal acceleration of a pendulum is effected by the starting of an angle inclination of a pendulum, which is represented by a playground swing. Attaching an Accelerometer to a swing and starting it from various angles will measure this.
\end{abstract}




\section{Introduction:}

Centripetal acceleration is the center-seeking acceleration of an object moving in a circle at a constant speed. However, it is also the rate of change of tangential velocity ("Centripetal Acceleration"). A tangential velocity changes as an object rotates. Such a vector, when increased, leads to faster centripetal accelerations.

Using this knowledge, we are aiming to determining what relationship the magnitude of an angle and centripetal acceleration share. In the case of this lab our object is a swing. We hypothesize that the greater the incline between a swing and its crossbar, the faster the centripetal acceleration the swing undergoes.

\section{Methods:}

Before beginning our experiment we must first connect the Accelerometer to a calculator in order to collect the needed data. In the calculator there should be an application called Easy Data, in the main screen of this application select Time Graph. When setting up the Time Graph, enter 0.2 seconds as the time between samples. Then enter the number of samples; for the purpose of this experiment we will be collecting hundred samples for each of the nine tests.

Once the calculator is set, orient the Accelerometer vertically on the chain of the swing so that the sensor is facing upward toward the crossbar. With the sensor motionless, select Zero under the Setup screen in the calculator. Now you are ready to begin collecting data.

Hold the inclinometer parallel to the Accelerometer on the opposite chain. This will allow us to ensure that the swing is set back to the proper angle. The initial angle we will be using is 10 degrees. Have the person seated in the swing push the swing back until 
the string hanging from the inclinometer reads 10 degrees. Then, with the calculator and Accelerometer set, the person on the swing is to then let the swing go. Once the swing has been released, the person in control of the calculator should press start to begin collecting data. When the data collection is complete, a graph displaying acceleration vs. time should appear. Using the cursor keys, find the point on the graph that shows the maximum centripetal acceleration. Remember, maximum centripetal acceleration is reached when the swing is vertical to the crossbar (see figure 1).

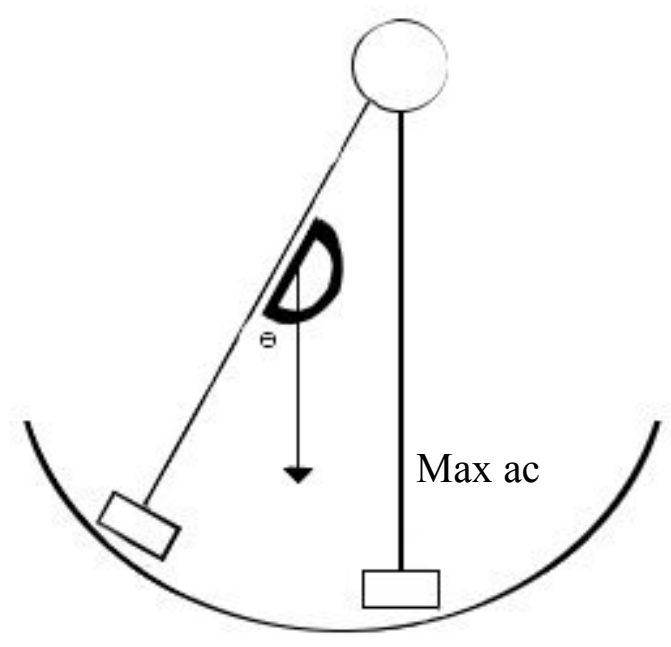

Record this acceleration and repeat the same procedure two more times with the same angle of 10 degrees. Once the results have been recorded you should have three accelerations listed for trial 1 . Find the average max centripetal acceleration by adding these three accelerations and dividing by three.

Using the same process, conduct two more trials, increasing the angle by another ten degrees for each one. The mass on the swing is to remain constant for all three trials, so whoever was initially seated on the swing should be there for the duration of the lab. If our hypothesis is accurate, the greater the angle, the faster our accelerations should be. 


\section{Results:}

\begin{tabular}{|c|c|c|c|}
\hline Trial & $\begin{array}{c}\text { Angle } \\
(\text { Degrees })\end{array}$ & $\begin{array}{c}\text { Max Centripetal } \\
\text { Acceleration } \\
(\mathrm{m} / \mathrm{s} 2)\end{array}$ & $\begin{array}{c}\text { Average Max Centripetal } \\
\text { Acceleration } \\
(\mathrm{m} / \mathrm{s} 2)\end{array}$ \\
\hline 1 & 10 & 15.76 & 16.02 \\
\hline 2 & 20 & 16.43 & 17.17 \\
& & 15.87 & 17.64 \\
\hline 3 & 30 & 17.55 & \\
\hline
\end{tabular}

The table displays how the angle of the swing before being released determines the centripetal acceleration of the swing itself. In trial 1 the swing, when held at an incline of 10 degrees and then let go, has an average centripetal acceleration of 16.02 $\mathrm{m} / \mathrm{s}^{2}$. In trial 2 we can see that when the angle from trial 1 is increased by 10 degrees, the average centripetal acceleration increases by $1.15 \mathrm{~m} / \mathrm{s}^{2}$. In our final trial, similar results are obtained. In again increasing the angle by another 10 degrees, thereby bringing the incline to 30 degrees, the acceleration is raised to $17.64 \mathrm{~m} / \mathrm{s}^{2}$.

Based on the results described there is a direct relationship between the angle of the swing and the resulting acceleration. A greater angle between the swing and its crossbar causes a faster centripetal acceleration. This trend is more clearly demonstrated in the following graph. 


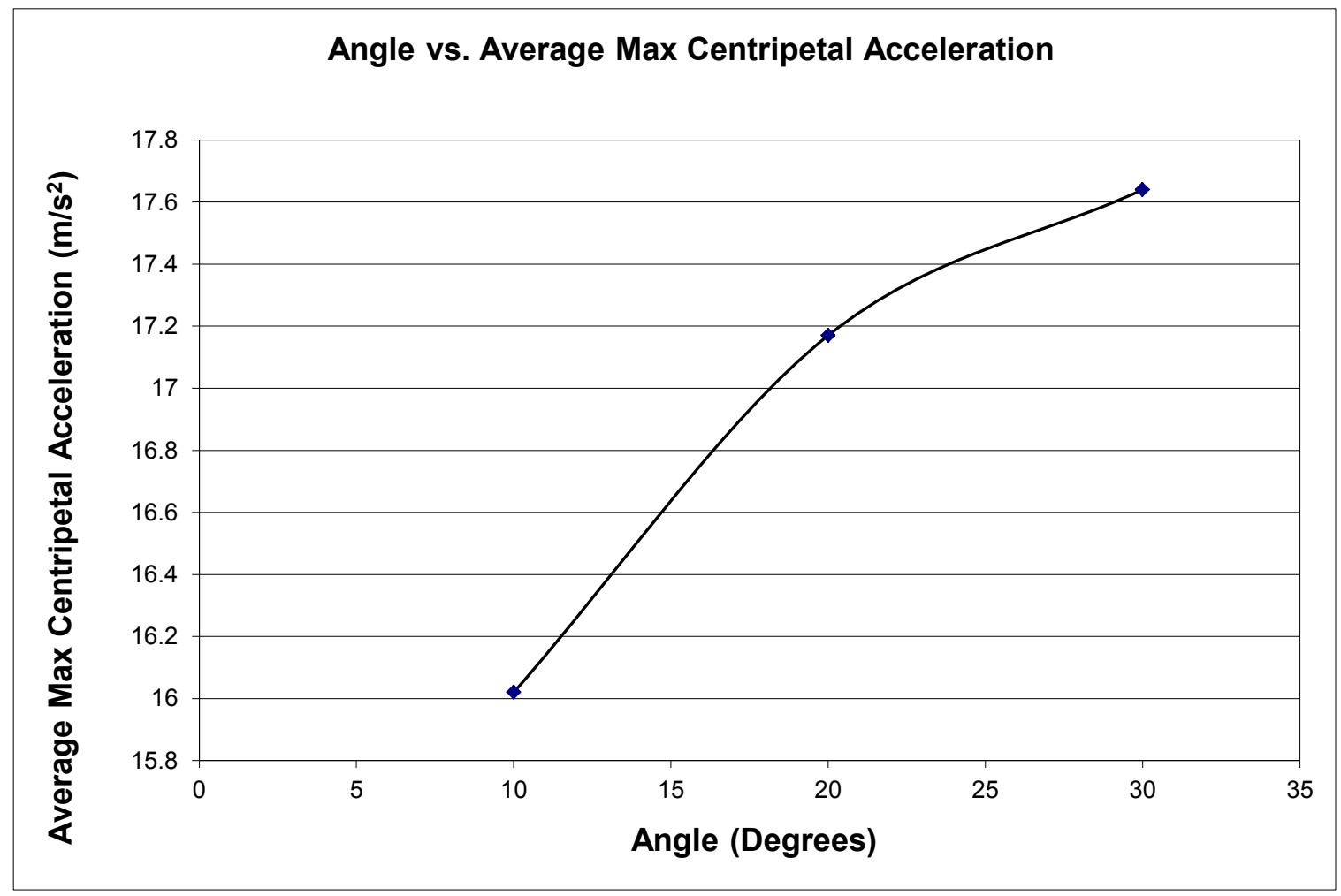

\section{Discussion:}

Looking closer at our experiment, it is safe to deduct that the reason the swing's centripetal acceleration increased with each addition of ten degrees was due to the force of gravity (see figure 2). With a greater angle, gravity has more time to act on the swing, building the tangential velocity and thereby increasing the centripetal acceleration. However, with a smaller angle, gravity has less time to influence the swing and if gravity has less time to influence the swing, the smaller the

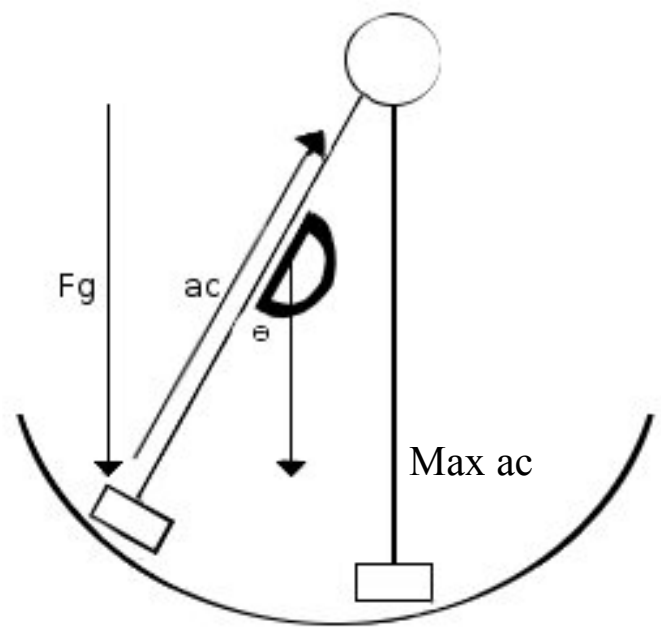


tangential velocity and the slower the centripetal acceleration.

For further study, we could switch the roles of two variables: mass and angle. In our experiment we chose to leave the mass constant by having only one person seated in the swing for the lab while our angle changed. Had we instead left the angle at a constant value and changed the mass each trial, we would be able to demonstrate the connection mass has to centripetal acceleration. Another variable that could be altered for

further experimentation is the chain. Chain is flexible. In the future it would be beneficial to use a solid rod to keep the swing from going slack at certain angles.

\section{Conclusion:}

When we set out to do this lab, we wanted to determine the relationship between centripetal acceleration and a given angle. Our results verified that as the angle between the swing's crossbar and its chain increased, the acceleration also augmented. These findings show that our hypothesis, which states that an increase of the incline between a swing and its crossbar will result in a greater centripetal acceleration, is plausible. 


\section{Works Cited}

"Centripetal Acceleration." N.p., 9 Oct. 1997. Web. 22 May 2010.

$<$ http://theory.uwinnipeg.ca/physics/circ/node6.html $>$. 